Article

\title{
Hydrogen Production via the Oxy-Steam Reforming of LNG or Methane on Ni Catalysts
}

\author{
Pawel Mierczynski *(D), Natalia Stępińska, Magdalena Mosinska, Karolina Chalupka, \\ Jadwiga Albinska, Waldemar Maniukiewicz ${ }^{\mathbb{D}}$, Jacek Rogowski, Magdalena Nowosielska and \\ Malgorzata I. Szynkowska *(D) \\ Institute of General and Ecological Chemistry, Lodz University of Technology, Zeromskiego 116, \\ 90-924 Lodz, Poland; natalia.stepinska1996@gmail.com (N.S.); magdalena.mosinska@dokt.p.lodz.pl (M.M.); \\ karolina.chalupka@p.lodz.pl (K.C.); jadwiga.albinska@p.lodz.pl (J.A.); \\ waldemar.maniukiewicz@p.lodz.pl (W.M.); jacek.rogowski@p.lodz.pl (J.R.); \\ magdalena.nowosielska@p.lodz.pl (M.N.) \\ * Correspondence: pawel.mierczynski@p.lodz.pl (P.M.); malgorzata.szynkowska@p.lodz.pl (M.I.S.); \\ Tel.: +48-42-631-31-25 (P.M.); +48-42-631-30-99 (M.I.S.)
}

Received: 25 February 2020; Accepted: 17 March 2020; Published: 20 March 2020

check for updates

\begin{abstract}
Ni catalysts supported on $\mathrm{ZrO}_{2}, 5 \% \mathrm{CeO}_{2}-\mathrm{ZrO}_{2}$, and $5 \% \mathrm{La}_{2} \mathrm{O}_{3}-\mathrm{ZrO}_{2}$ were prepared via the impregnation method and tested in the oxy-steam reforming of methane and liquified natural gas (LNG). All tested catalysts exhibited high catalytic activity in the studied process at 700 and $900{ }^{\circ} \mathrm{C}$. The improvement of the stability of $\mathrm{Ni}$ catalysts after the addition of $\mathrm{CeO}_{2}$ oxide in the studied oxy-steam reforming of LNG process was confirmed. In addition, high activity and selectivity towards hydrogen was proven in the oxy-steam reforming process at $900{ }^{\circ} \mathrm{C}$ over a $20 \% \mathrm{Ni} / 5 \% \mathrm{CeO}_{2}-\mathrm{ZrO}_{2}$ catalyst. It was also proved that the addition of $\mathrm{CeO}_{2}$ onto a $\mathrm{ZrO}_{2}$ carrier leads to a decrease in the $\mathrm{NiO}$ and metallic $\mathrm{Ni}$ crystallite sizes that were detected by the X-Ray diffraction (XRD) technique. The solid solution formation between $\mathrm{NiO}$ and $\mathrm{ZrO}_{2}$ and/or $\mathrm{NiO}$ and $\mathrm{CeO}_{2}$ was proved. Superior reactivity in the oxy-steam reforming of $\mathrm{CH}_{4}$ and the $\mathrm{LNG}$ process exhibited a $20 \% \mathrm{Ni} / \mathrm{ZrO}{ }_{2}$ catalyst, which showed the highest methane conversions at 500 and $600{ }^{\circ} \mathrm{C}$, equal to $63 \%$ and $89 \%$, respectively. In addition, also in the case of the LNG reforming reaction, the most active catalyst was the $20 \% \mathrm{Ni} / \mathrm{ZrO}_{2}$ system, which demonstrated $46.3 \%$ and $76.9 \%$ of the methane conversion value at 500 and $600{ }^{\circ} \mathrm{C}$ and the total conversion of others hydrocarbons (ethane, propane and butane). In addition, this catalytic system exhibited the highest selectivity towards hydrogen formation in the oxy-steam reforming of the LNG reaction equal to $71.2 \%$ and $71.3 \%$ at 500 and $600{ }^{\circ} \mathrm{C}$, respectively. The highest activity of this system can be explained by the uniform distributions of $\mathrm{Ni}$ species and their highest concentration compared to the rest of the monometallic Ni catalysts. Time-of-flight secondary ion mass spectrometry (ToF-SIMS) results also confirmed a strong interaction of $\mathrm{NiO}$ with $\mathrm{ZrO}_{2}$ in the case of the $20 \% \mathrm{Ni} / \mathrm{ZrO}_{2}$ catalysts. The presence of selected $\mathrm{NiZrO}^{+}$ions emitted from the investigated surface of the $20 \% \mathrm{Ni} / \mathrm{ZrO}_{2}$ system was detected.
\end{abstract}

Keywords: reforming of methane; $\mathrm{LNG}$; nickel catalysts; syngas; $\mathrm{ZrO}_{2}$; reforming of liquid natural gas

\section{Introduction}

The development of civilization, the progressive degradation of the environment, and the growing scarcity of raw materials, especially energetic, caused an increased interest in alternative energy sources and the modern technologies involved in their production. Accordingly, studies of many research and development centers are focused not only on issues related to the production, transport, storage, and use of hydrogen energy, but also are related to the search for new methods of producing high 
purity hydrogen, which is directly related to the use of fuel cell technology [1-5]. Currently, the main technologies of the hydrogen production are based on the steam reforming of natural gas. The hydrogen production via the reforming process of natural gas consists of two stages. The first step is connected with the purification of natural gas from the sulphur and nitrogen compounds. The second step involves the proper steam reforming of methane and higher hydrocarbons. A two-stage process makes it impossible to obtain hydrogen in one reaction act. The solution of this problem is liquefied natural gas (LNG) [6,7]. The main component of LNG is methane, whose content ranges from $88.4 \%$ to $99.7 \%$ and its other components include ethane $(0.1-13.4 \%)$, propane $(0-3.7 \%), \mathrm{C}_{4}$ $(0-1.5 \%)$, and nitrogen $(0-0.8 \%)$. After the condensation of the natural gas, a very pure, colourless, and odourless gas mixture mainly consisting of hydrocarbons is obtained without toxic and corrosive properties [8]. Therefore, hydrogen production via the steam reforming of liquefied natural gas (LNG) can be a promising route due to well-established LNG supply infrastructures and wide-spreading LNG pipelines in the modern cities [6].

A typical catalyst used in the reforming of natural gas was $\mathrm{Ni} / \mathrm{Al}_{2} \mathrm{O}_{3}$-based catalysts [9-11]. Many scientists have investigated the influence of the different promotors on the catalytic activity, stability, and selectivity of $\mathrm{Ni}$ catalysts in reforming processes. Some authors reported an improvement in the $\mathrm{Ni}$ catalysts stability after $\mathrm{CeO}_{2}$ addition into an Ni system. In addition, some evidence that cerium oxide stabilizes $\mathrm{Al}_{2} \mathrm{O}_{3}$ support and provides the mobile oxygen during oxidation and reduction conditions can also be found [12-14]. It is also known that cerium oxide addition improves the catalytic activity and protects against a carbon build-up of Ni-based catalysts [13]. On the other hand, the addition of $\mathrm{La}_{2} \mathrm{O}_{3}$ oxide into an Ni-based system, increasing the $\mathrm{NiO}$ dispersion on the support surface, facilitates the reduction of the $\mathrm{NiO}$ phase. This modifier facilitates the oxidation of carbon forms created on the catalyst surface and limits the carbon deposit formation during the reforming of the methane process, which leads to increasing the Ni catalyst's stability $[15,16]$.

Therefore, the main aim of this work was to determine the effect of $\mathrm{Ni}$ and the influence of the modifiers on the physicochemical and catalytic properties of nickel catalysts in the oxy-steam reforming of methane or LNG reaction. In order to achieve the intended purposes of the presented work, monometallic nickel catalysts supported on $\mathrm{ZrO}_{2}, 5 \% \mathrm{CeO}_{2}-\mathrm{ZrO}_{2}, 5 \% \mathrm{La}_{2} \mathrm{O}_{3}-\mathrm{ZrO}_{2}$ with different loadings $(5,10,20,30 \%$ wt.) of Ni were prepared by the impregnation method. Their physicochemical properties were extensively studied by Brunauer-Emmett-Teller (BET), Temperature-Programmed-Reduction in hydrogen (TPR- $\mathrm{H}_{2}$ ), Temperature-Programmed-Desorption of ammonia (TPD- $\mathrm{NH}_{3}$ ), XRD, Scanning Electron Microscope with EDS detector (SEM-EDS), and Thermal Analysis coupled with Mass Spectrometer (TG-DTA-MS) techniques. In order to correlate the catalytic activity of the catalysts with their physicochemical properties in the oxy-steam reforming of methane or LNG catalytic activity, measurements were done using a fixed bed micro-reactor under atmospheric pressure in the temperature range $500-900{ }^{\circ} \mathrm{C}$.

\section{Results and Discussion}

\subsection{Activity Tests}

Catalytic tests in the oxy-steam reforming of methane were performed in the fixed bed microreactor under atmospheric pressure in the temperature range $500-900{ }^{\circ} \mathrm{C}$. In the first step of the activity measurements, the influence of $\mathrm{Ni}$ loading on the catalytic activity of monometallic systems $\left(\mathrm{Ni} / \mathrm{ZrO}_{2}\right)$ in the oxy-steam reforming of methane reaction was studied. The activity measurements were expressed as methane conversions, selectivity towards $\mathrm{CO}$ and $\mathrm{CO}_{2}$, and hydrogen yield. The results obtained for Ni catalysts containing 5, 10, 20 ad 30\% wt. of $\mathrm{Ni}$ are given in Figure 1 . The activity results show that the highest methane conversion at $700{ }^{\circ} \mathrm{C}$, the yield of the hydrogen formation, and the highest molar ratio between $\mathrm{H}_{2}$ and $\mathrm{CO}$ was obtained $\left(\mathrm{H}_{2} / \mathrm{CO}=2.0\right.$ at $\left.700{ }^{\circ} \mathrm{C}\right)$ for $30 \% \mathrm{Ni} / \mathrm{ZrO}_{2}$ catalyst. At $900{ }^{\circ} \mathrm{C}$, the highest hydrogen yield was obtained using the $20 \% \mathrm{Ni} / \mathrm{ZrO}_{2}$ catalyst. From the application point of view, for the next catalytic tests, we selected a system containing $20 \% \mathrm{wt}$. of $\mathrm{Ni}$ due to the lower content of nickel in the catalytic system and the fact that this system is characterized 
by high methane conversion and efficiency in the production of hydrogen. Next, the influence of structural additives such as $\mathrm{CeO}_{2}$ or $\mathrm{La}_{2} \mathrm{O}_{3}$ on the catalytic and physicochemical properties of the $20 \% \mathrm{Ni} / \mathrm{ZrO}_{2}$ catalyst was also studied in this work and the results are shown in Figure 2 . The activity tests performed for the catalysts containing $20 \%$ wt. of Ni showed that the reaction runs from $500{ }^{\circ} \mathrm{C}$. At this temperature, the highest activity was obtained using the $20 \% \mathrm{Ni} / \mathrm{ZrO}_{2}$ system, which exhibited $7.4 \%$ of methane conversion compared to the nickel catalysts with $\mathrm{CeO}_{2}$ and $\mathrm{La}_{2} \mathrm{O}_{3}$ addition. At $600{ }^{\circ} \mathrm{C}$ the highest methane conversion of $13.9 \%$ was observed for catalysts with $5 \% \mathrm{La}_{2} \mathrm{O}_{3}$ addition. Meanwhile, further increasing the reaction temperature up to $700{ }^{\circ} \mathrm{C}$ showed that the $20 \% \mathrm{Ni} / \mathrm{ZrO}_{2}$ and $20 \% \mathrm{Ni} / 5 \% \mathrm{La}_{2} \mathrm{O}_{3}-\mathrm{ZrO}_{2}$ catalysts exhibited practically the same methane conversion above $97 \%$. Whereas, the $20 \% \mathrm{Ni} / 5 \% \mathrm{CeO}_{2}-\mathrm{ZrO}_{2}$ system showed the $\mathrm{CH}_{4}$ conversion was equal to $86.7 \%$ together with the highest hydrogen yield (70.7\%). It should be also noted that all Ni catalysts with $20 \%$ of nickel loading showed total conversion of methane at $900{ }^{\circ} \mathrm{C}$.
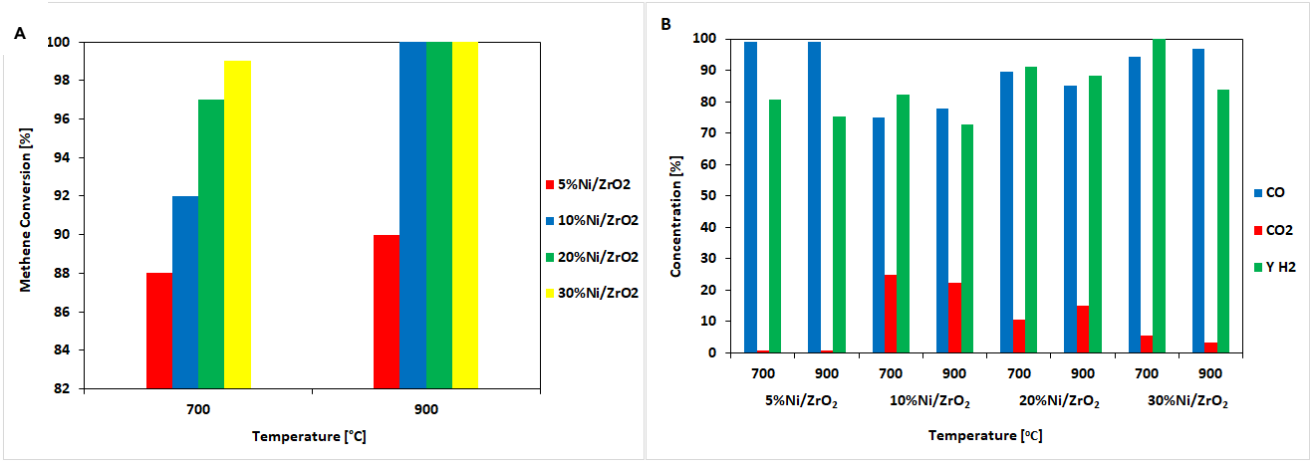

Figure 1. Catalytic activity results obtained for monometallic $\mathrm{Ni} / \mathrm{ZrO}_{2}$ catalysts in the oxy-steam reforming of methane expressed as methane conversion, and the selectivity of the $\mathrm{CO}$ and $\mathrm{CO}_{2}$ and hydrogen yield formed during the process. (A) Methane conversion. (B) The selectivity towards CO and $\mathrm{CO}_{2}$ and hydrogen yield.

Furthermore, the $20 \% \mathrm{Ni} / \mathrm{ZrO}_{2}$ catalyst exhibited the highest hydrogen formation (64.6\%), and the highest $\mathrm{H}_{2} / \mathrm{CO}$ molar ratio was equal to 2.2 during the investigated process. It should be also emphasized that this catalyst exhibited the highest selectivity towards hydrogen generation at 700 and $900{ }^{\circ} \mathrm{C}$ among of all investigated catalysts containing $20 \%$ wt. of $\mathrm{Ni}$.

In the next step of the catalytic activity measurements, the oxy-steam reforming of LNG was investigated. The oxy-steam reforming of LNG was investigated over a series of the catalysts containing $20 \%$ wt. of $\mathrm{Ni}$, and the catalytic measurements are shown in Figures 3-5. The results of the activity measurements showed that, starting from $400{ }^{\circ} \mathrm{C}$, we observed the conversion of methane, ethane, propane, and butane equal to $18.8 \%, 24.7 \%, 36.8 \%$, and $100 \%$ in the oxy-steam reforming of LNG over $20 \% \mathrm{Ni} / \mathrm{ZrO}_{2}$ catalyst, respectively (see Figure 3 ). On the other hand, the activity results show that when the reaction is carried out at $400{ }^{\circ} \mathrm{C}$ using a $20 \% \mathrm{Ni} / 5 \% \mathrm{La}_{2} \mathrm{O}_{3}-\mathrm{ZrO}_{2}$ catalyst, only a low conversion of propane and butane was detected (see Figure 4). While, $20 \% \mathrm{Ni} / 5 \% \mathrm{CeO}_{2}-\mathrm{ZrO}_{2}$ catalysts also exhibited lower conversion values compared to the not-promoted Ni catalyst ( $43.7 \%$ of butane, $22.2 \%$ of propane, $11.9 \%$ of ethane, and $4.6 \%$ of methane, see Figure 5 ). Increasing the reaction temperature up to $500{ }^{\circ} \mathrm{C}$ results in $100 \%$ of ethane, propane and butane conversions during the reaction performed on $20 \% \mathrm{Ni} / \mathrm{ZrO}_{2}$ catalysts. Whereas, the catalytic activity results obtained for the promoted catalysts confirmed the incomplete conversion of methane, ethane, and propane. Further raising the reaction temperature up to $600{ }^{\circ} \mathrm{C}$ resulted in the full conversion of the higher hydrocarbons (ethane, propane, butane) for the $20 \% \mathrm{Ni} / \mathrm{ZrO}$ and $20 \% \mathrm{Ni} / 5 \% \mathrm{CeO}_{2}-\mathrm{ZrO}_{2}$ systems. However, in the case of the $20 \% \mathrm{Ni} / 5 \% \mathrm{La}_{2} \mathrm{O}_{3}-\mathrm{ZrO}_{2}$ system, we also detected an incomplete conversion of ethane and propane. At $600{ }^{\circ} \mathrm{C}$, the highest hydrogen yield formation had $20 \% \mathrm{Ni} / \mathrm{ZrO}_{2}$ catalyst $(74 \%)$. The results obtained at 700 and $900{ }^{\circ} \mathrm{C}$ gave evidence that in all cases we observed the total conversion of the higher hydrocarbons (ethane, propane, and butane) and that the methane conversion was above $94 \%$. It is 
also worth mentioning that the promoted $\mathrm{Ni}$ catalysts $\left(20 \% \mathrm{Ni} / 5 \% \mathrm{La}_{2} \mathrm{O}_{3}-\mathrm{ZrO}_{2}, 20 \% \mathrm{Ni} / 5 \% \mathrm{CeO}_{2}-\mathrm{ZrO}_{2}\right)$ showed higher hydrogen yield together with a high molar ratio between the created products of $\mathrm{H}_{2} / \mathrm{CO}$ at $700{ }^{\circ} \mathrm{C}$ compared to the $20 \% \mathrm{Ni} / \mathrm{ZrO}_{2}$ catalyst.

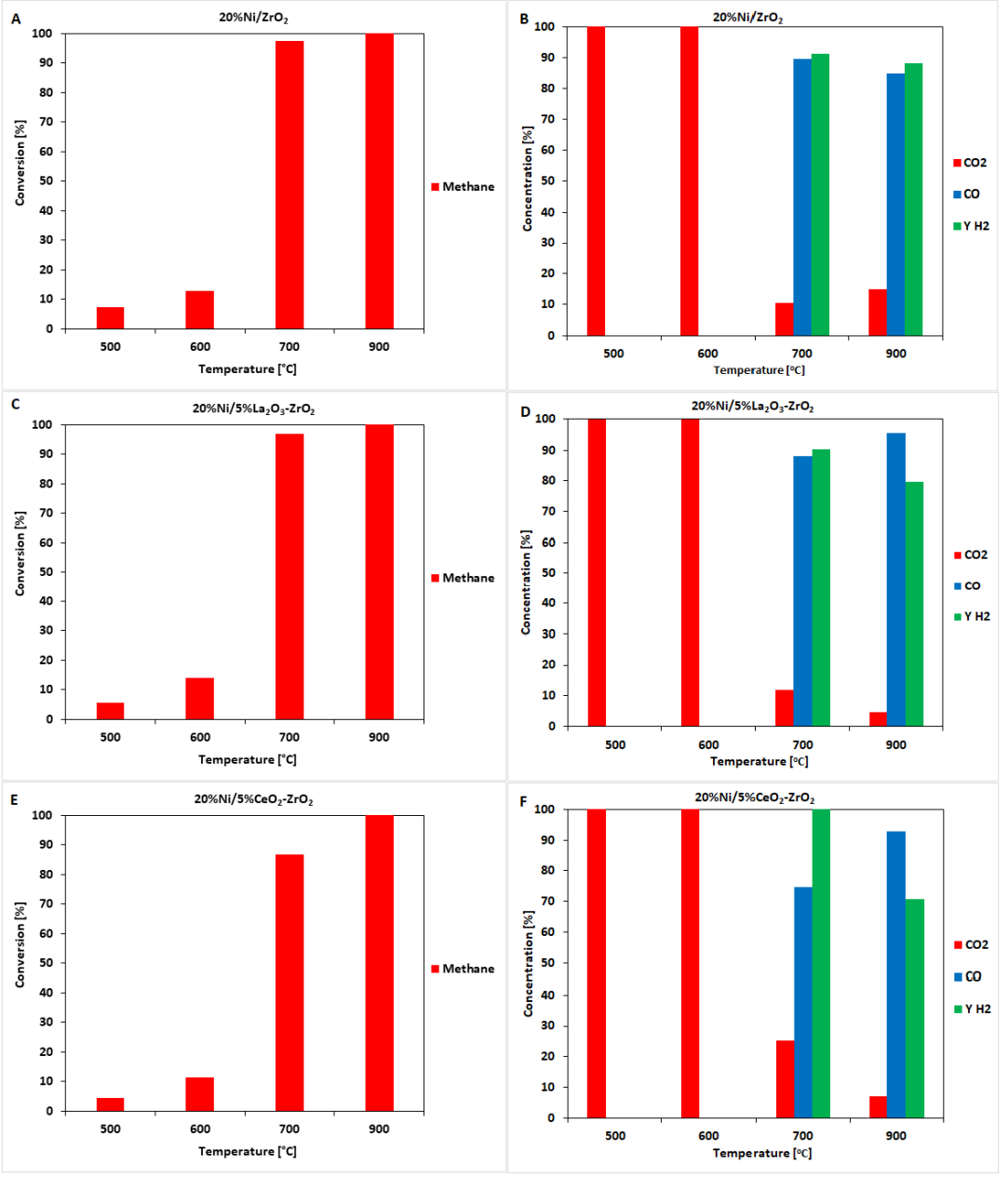

Figure 2. Catalytic activity results obtained in the oxy-steam reforming of methane expressed as methane conversion, and the selectivity of the $\mathrm{CO}$ and $\mathrm{CO}_{2}$ formed during the process and hydrogen yield. $(\mathbf{A}, \mathbf{B})-20 \% \mathrm{Ni} / \mathrm{ZrO}_{2},(\mathbf{C}, \mathbf{D})-20 \% \mathrm{Ni} / 5 \% \mathrm{La}_{2} \mathrm{O}_{3}-\mathrm{ZrO}_{2},(\mathbf{E}, \mathbf{F})-20 \% \mathrm{Ni} / 5 \% \mathrm{CeO}_{2}-\mathrm{ZrO}_{2}$.
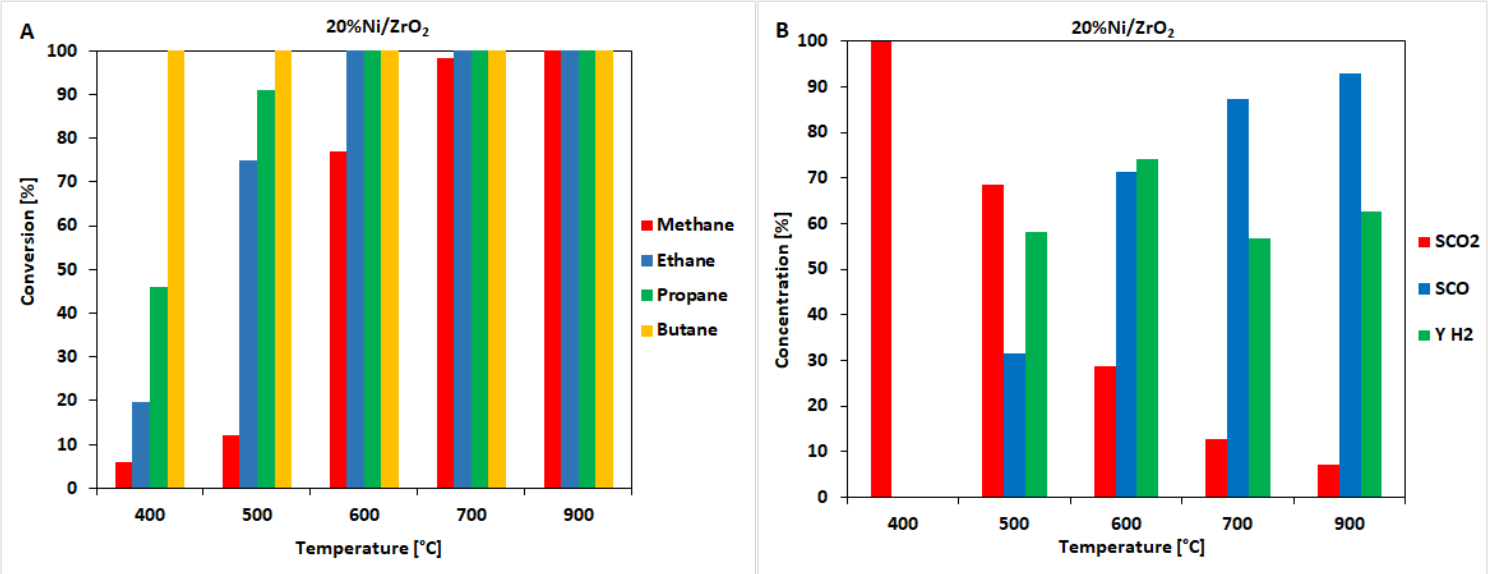

Figure 3. Results of the catalytic activity measurements performed in the temperature range $400-900{ }^{\circ} \mathrm{C}$ in the OSRM of a liquified natural gas (LNG) reaction on a $20 \% \mathrm{Ni} / \mathrm{ZrO}_{2}$ catalyst. (A) Hydrocarbon conversion. (B) The selectivity of $\mathrm{CO}$ and $\mathrm{CO}_{2}$ and hydrogen yield. 

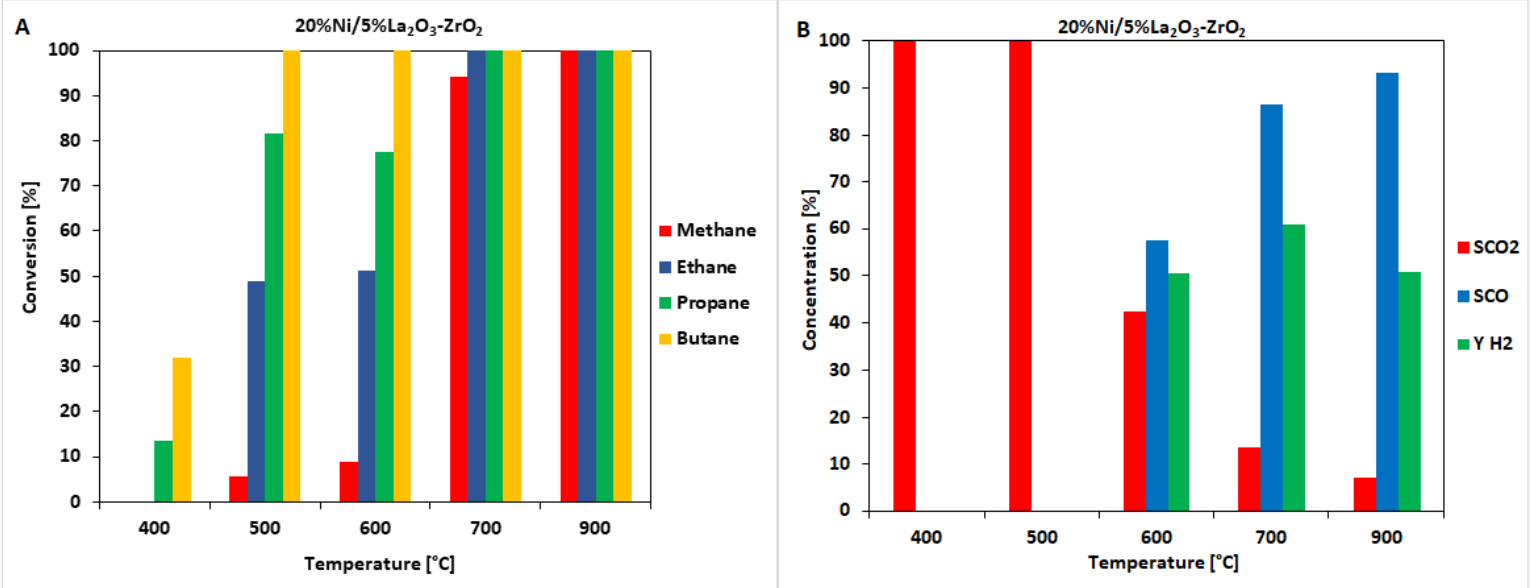

Figure 4. Results of the catalytic activity measurements performed in the temperature range $400-900{ }^{\circ} \mathrm{C}$ in the OSRM of the $\mathrm{LNG}$ reaction on a $20 \% \mathrm{Ni} / 5 \% \mathrm{La}_{2} \mathrm{O}_{3}-\mathrm{ZrO}_{2}$ catalyst. (A) Hydrocarbon conversion. (B) The selectivity of $\mathrm{CO}$ and $\mathrm{CO}_{2}$ and hydrogen yield.
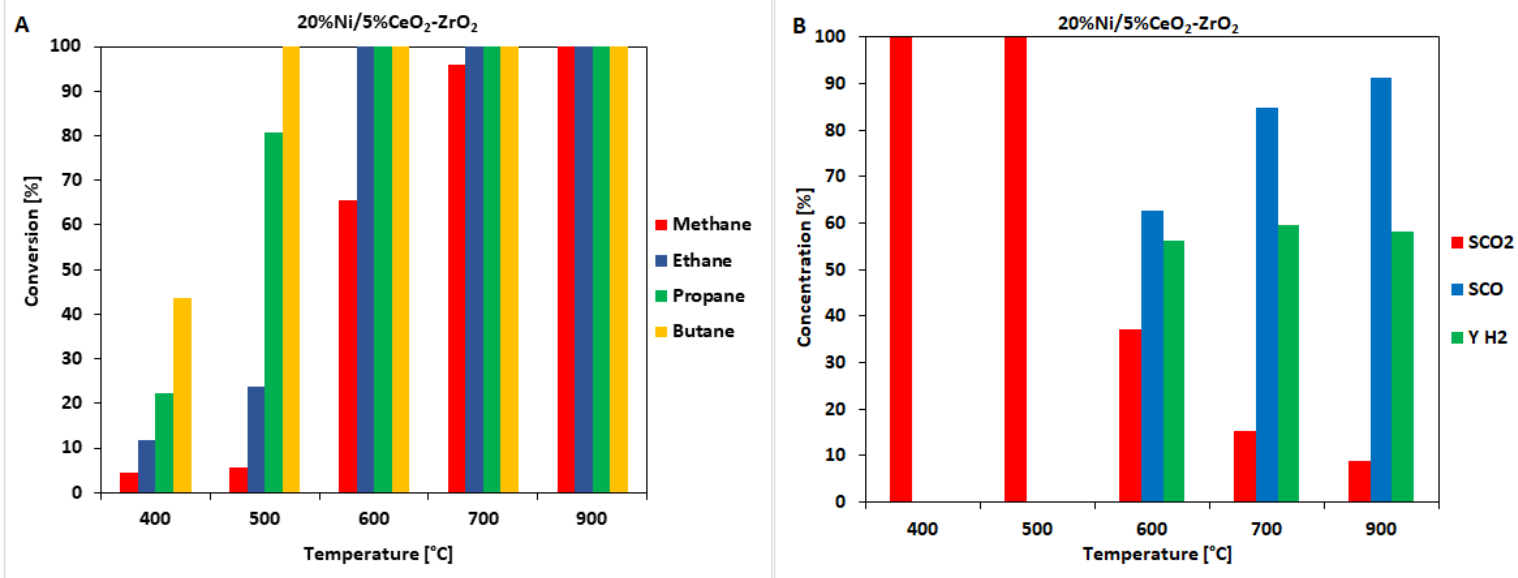

Figure 5. Results of the catalytic activity measurements performed in the temperature range $400-900{ }^{\circ} \mathrm{C}$ in the OSRM of the $\mathrm{LNG}$ reaction on a $20 \% \mathrm{Ni} / 5 \% \mathrm{CeO}_{2}-\mathrm{ZrO}_{2}$ catalyst. (A) Hydrocarbon conversion. (B) The selectivity of $\mathrm{CO}$ and $\mathrm{CO}_{2}$ and hydrogen yield.

On the other hand, the $20 \% \mathrm{Ni} / 5 \% \mathrm{CeO}_{2}-\mathrm{ZrO}_{2}$ and $20 \% \mathrm{Ni} / 5 \% \mathrm{La}_{2} \mathrm{O}_{3}-\mathrm{ZrO}_{2}$ catalysts exhibited a higher $\mathrm{H}_{2} / \mathrm{CO}$ molar ratio in the outlet gases during the reaction performed at 700 and $900{ }^{\circ} \mathrm{C}$. Summarizing the catalytic activity of the Ni catalysts performed in the oxy-steam reforming of LNG, it should be emphasized that above $600{ }^{\circ} \mathrm{C}$ the reaction runs in the same way as in the case of the oxy-steam reforming of the methane process. The main products observed in the outlet gases are $\mathrm{CO}_{2}, \mathrm{H}_{2}$, and $\mathrm{CO}$. It should be also noticed that at $600{ }^{\circ} \mathrm{C}$ we obtained very satisfactory results for the $20 \% \mathrm{Ni} / \mathrm{ZrO}_{2}$ and $20 \% \mathrm{Ni} / 5 \% \mathrm{CeO}_{2}-\mathrm{ZrO}_{2}$ catalyst. These systems showed a high conversion of methane, above $65 \%$, and a high yield of hydrogen generation equal to $74 \%$ and $56 \%$ for the $20 \% \mathrm{Ni} / \mathrm{ZrO}_{2}$ and $20 \% \mathrm{Ni} / 5 \% \mathrm{CeO}_{2}-\mathrm{ZrO}_{2}$ catalysts, respectively. It should be also noticed that both the $20 \% \mathrm{Ni} / 5 \% \mathrm{CeO}_{2}-\mathrm{ZrO}_{2}$ and $20 \% \mathrm{Ni} / 5 \% \mathrm{La}_{2} \mathrm{O}_{3}-\mathrm{ZrO}_{2}$ catalysts exhibited high hydrocarbon conversions and the higher hydrogen yield at $700{ }^{\circ} \mathrm{C}$ compared to the $20 \% \mathrm{Ni} / \mathrm{ZrO}_{2}$ system. While, at $900{ }^{\circ} \mathrm{C}$, the highest hydrogen yield was obtained using $20 \% \mathrm{Ni} / \mathrm{ZrO}_{2}$, which exhibited a total conversion of methane and other hydrocarbons. These results confirm the possibility of using LNG for hydrogen production to power fuel cells.

$\mathrm{Next}$, the catalytic tests during the $12 \mathrm{~h}$ of the reaction for the $20 \% \mathrm{Ni} / \mathrm{ZrO} \mathrm{Z}_{2}, 20 \% \mathrm{Ni} / 5 \% \mathrm{La}_{2} \mathrm{O}_{3}-\mathrm{ZrO}_{2}$ and $20 \% \mathrm{Ni} / 5 \% \mathrm{CeO}_{2}-\mathrm{ZrO}_{2}$ were carried out in the oxy-steam LNG reforming process at $700{ }^{\circ} \mathrm{C}$, and the results are given in Figures 6-8, respectively. The results of the time-on-stream catalytic tests 
showed that all investigated catalysts were stable during the process. It should be emphasized that the $\mathrm{Ni}$ catalyst with $\mathrm{La}_{2} \mathrm{O}_{3}$ addition exhibited stable methane conversion equal to $99 \%$ and other light hydrocarbon conversions (ethane, propane, butane) after $4 \mathrm{~h}$ of the running the process. Other tested catalysts showed slight changes in methane conversion values during the period of catalytic tests. In addition, all three catalysts showed very similar selectivity towards $\mathrm{CO}$ and $\mathrm{CO}_{2}$ and hydrogen yield.
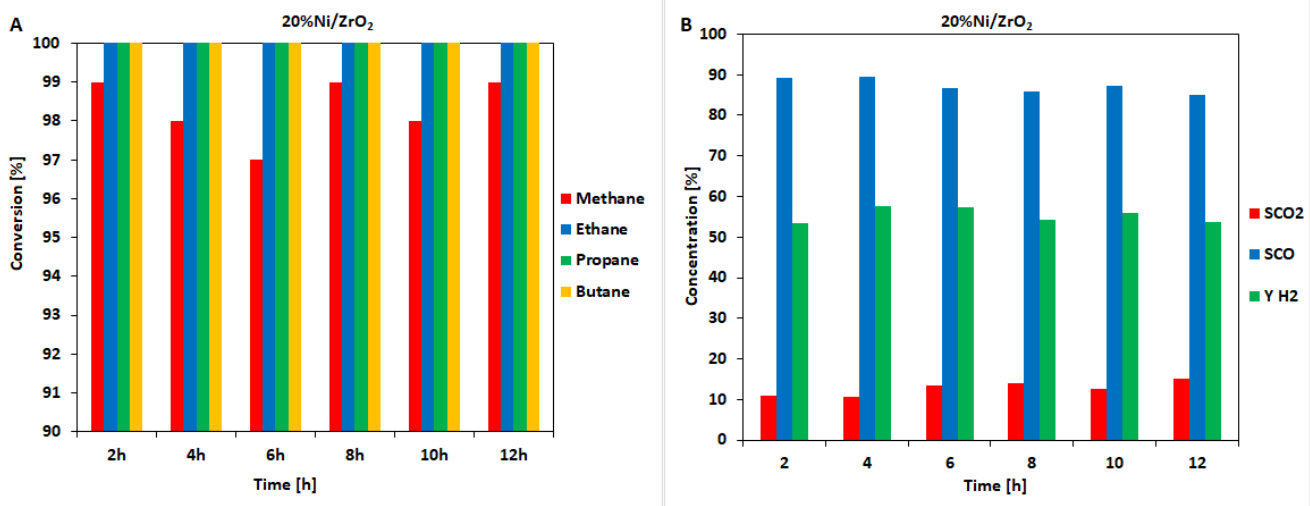

Figure 6. Results of the time-on-stream catalytic tests performed during $12 \mathrm{~h}$ of the OSRM of the LNG reaction on a $20 \% \mathrm{Ni} / \mathrm{ZrO}_{2}$ catalyst. (A) Hydrocarbon conversion. (B) The selectivity of $\mathrm{CO}$ and $\mathrm{CO}_{2}$ and hydrogen yield.
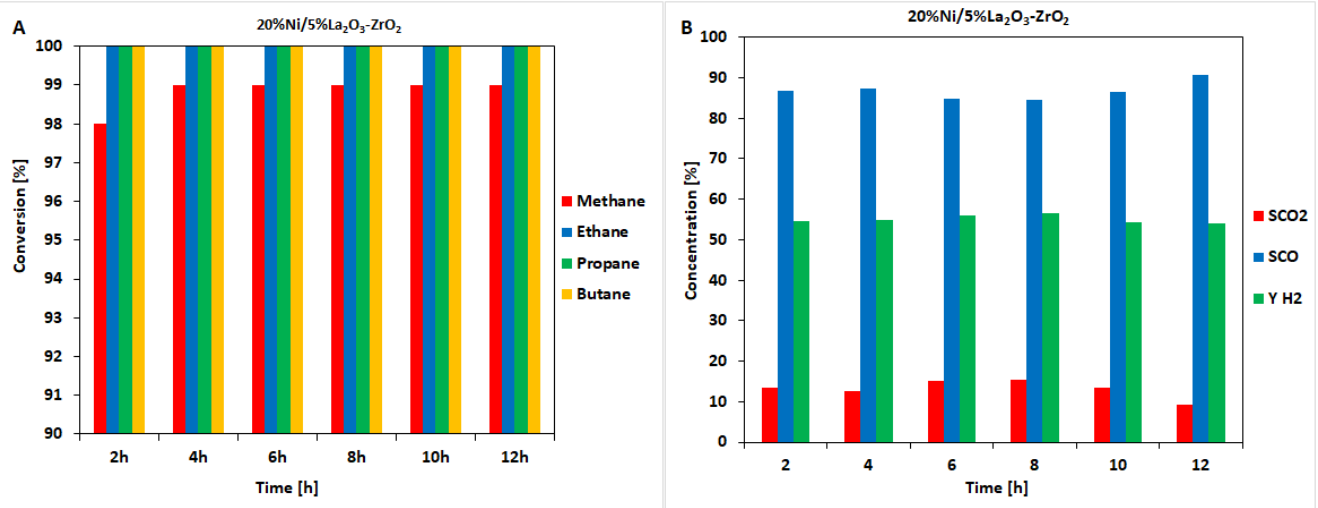

Figure 7. Results of the time-on-stream catalytic tests performed during $12 \mathrm{~h}$ of the OSRM of the LNG reaction on a $20 \% \mathrm{Ni} / 5 \% \mathrm{La}_{2} \mathrm{O}_{3}-\mathrm{ZrO}_{2}$ catalyst. (A) Hydrocarbon conversion. (B) The selectivity of the $\mathrm{CO}$ and $\mathrm{CO}_{2}$ and hydrogen yield.
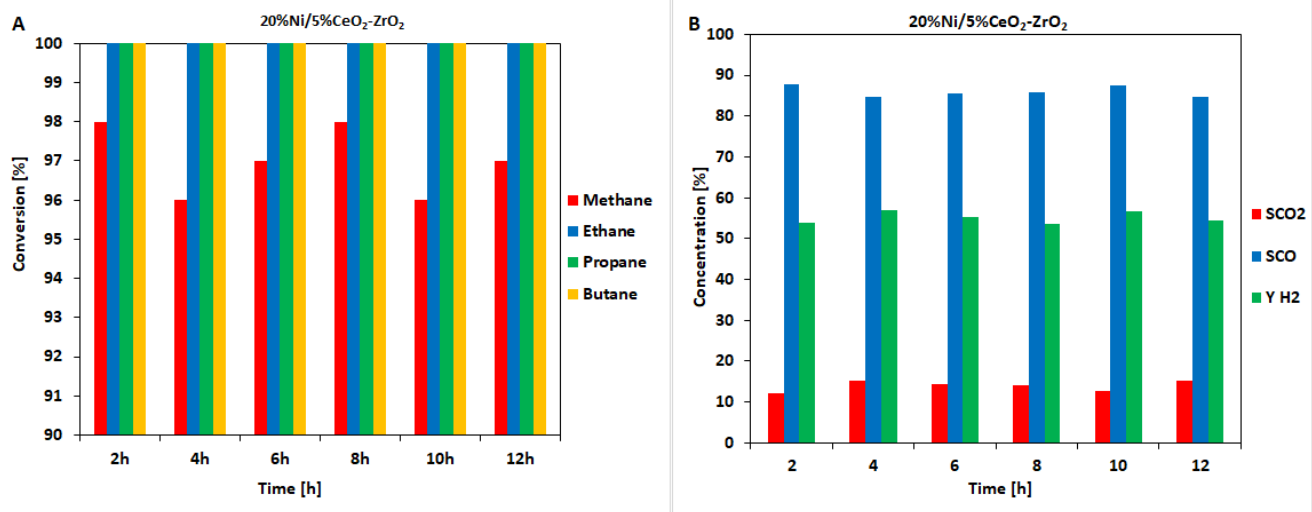

Figure 8. Results of the time-on-stream catalytic tests performed during $12 \mathrm{~h}$ of the OSRM of the LNG reaction on a $20 \% \mathrm{Ni} / 5 \% \mathrm{CeO}_{2}-\mathrm{ZrO}_{2}$ catalyst. (A) Hydrocarbon conversion. (B) The selectivity of the $\mathrm{CO}$ and $\mathrm{CO}_{2}$ and hydrogen yield. 


\subsection{Phase Composition Studies of the Catalytic Material}

In order to correlate the reactivity of the $\mathrm{Ni}$ catalysts with the properties in the oxy-steam reforming of the LNG process, their physicochemical properties were investigated using various research techniques. The phase composition studies of the supports and Ni-calcined catalysts were studied using a conventional XRD technique, and the results are shown in Figures 9 and 10. The phase composition studies of $\mathrm{ZrO}_{2}$ showed that this support consists of the tetragonal and monoclinic structure of the $\mathrm{ZrO}_{2}$ phase [17]. The XRD measurements performed for the calcined Ni systems confirmed the presence of the $\mathrm{NiO}$, tetragonal, and monoclinic crystallographic structure of $\mathrm{ZrO}_{2}$ phases on the diffraction patterns [11] (see Figure 9). The addition of $\mathrm{La}_{2} \mathrm{O}_{3}$ or $\mathrm{CeO}_{2}$ oxide into the $\mathrm{ZrO}_{2}$ structure did not cause any changes in the phase composition of the investigated catalytic material (see Figure 10). The diffraction curves recorded for the $20 \% \mathrm{Ni} / 5 \% \mathrm{CeO}_{2}-\mathrm{ZrO}_{2}$ and $20 \% \mathrm{Ni} / 5 \% \mathrm{La}_{2} \mathrm{O}_{3}-\mathrm{ZrO}_{2}$ catalysts showed the presence of the same crystallographic phases that were detected for the $\mathrm{Ni} / \mathrm{ZrO}{ }_{2}$ catalyst. The only differences were observed for the $20 \% \mathrm{Ni} / 5 \% \mathrm{CeO}_{2}-\mathrm{ZrO}_{2}$ catalyst. On the diffraction curve recorded for this system, the shift of the diffraction peaks assigned to the $\mathrm{ZrO}_{2}$ phases towards the lower 2 theta angle was observed compared to $20 \% \mathrm{Ni} / \mathrm{ZrO}_{2}$. These shifts of the diffraction peaks of zirconia may be explained by the presence of a solid solution between $\mathrm{CeO}_{2}$ and $\mathrm{ZrO}_{2}$ created during the preparation of the catalytic material.

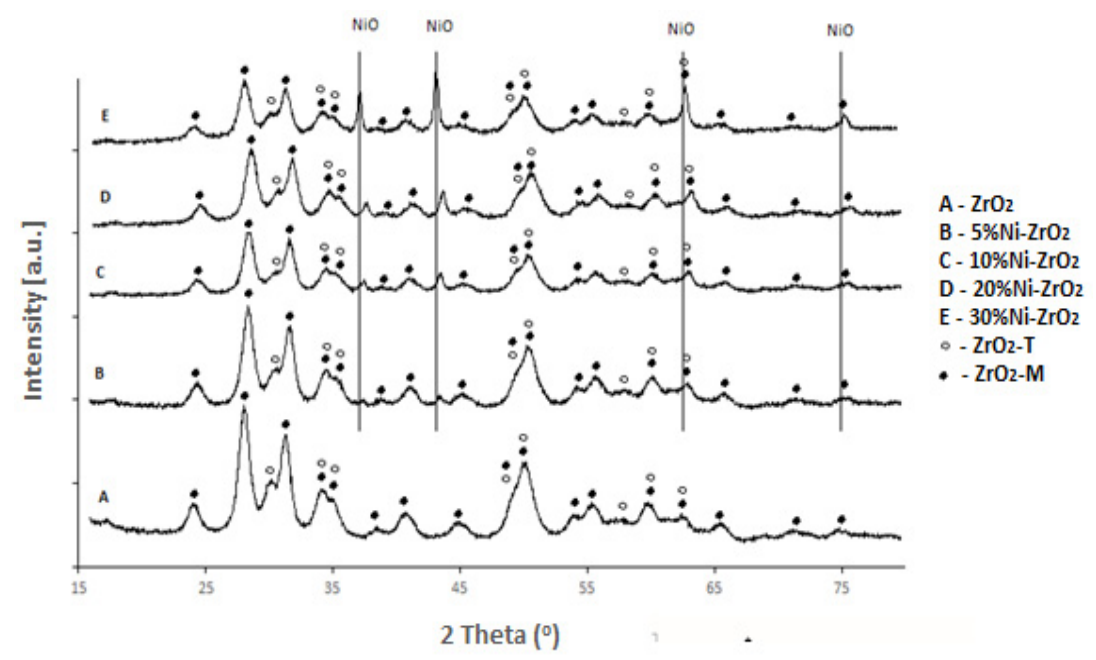

Figure 9. $\mathrm{XRD}$ curves of the $\mathrm{ZrO}_{2}$ and monometallic $\mathrm{Ni} / \mathrm{ZrO}_{2}$ catalysts calcined in an air atmosphere for 4 h at $400{ }^{\circ} \mathrm{C}$.

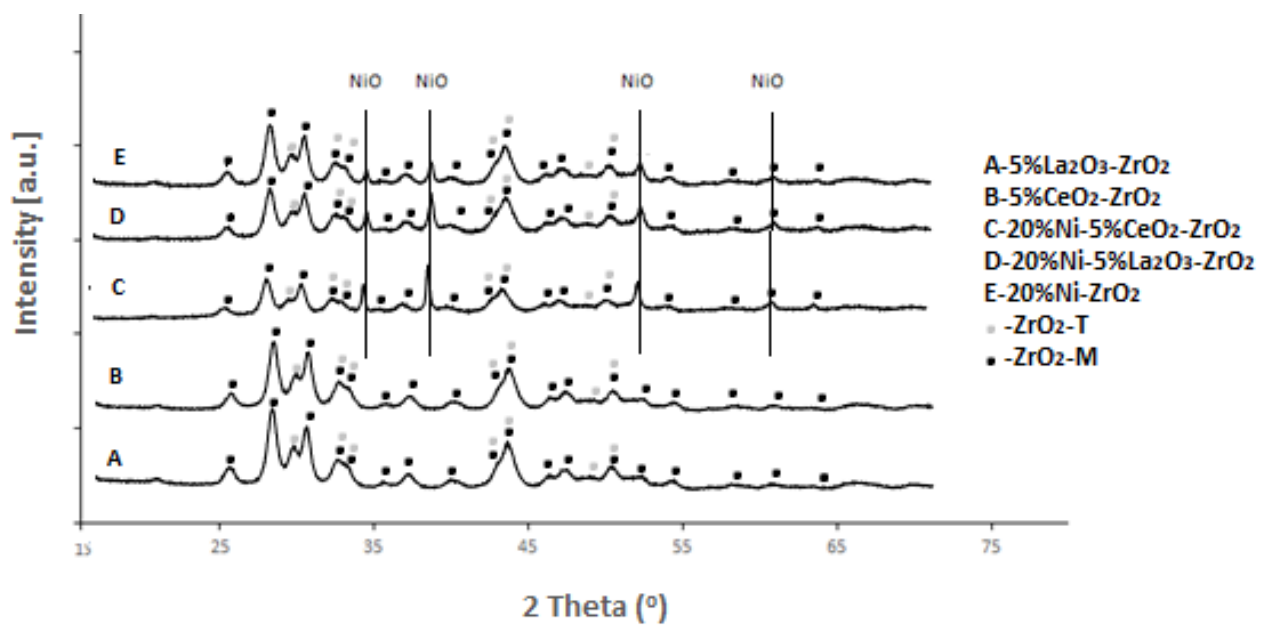

Figure 10. XRD curves of supports $5 \% \mathrm{La}_{2} \mathrm{O}_{3}-\mathrm{ZrO}_{2}, 5 \% \mathrm{CeO}_{2}-\mathrm{ZrO}_{2}$, and monometallic Ni catalysts supported on $\mathrm{ZrO}_{2}, 5 \% \mathrm{CeO}_{2}-\mathrm{ZrO}_{2}$, and $5 \% \mathrm{La}_{2} \mathrm{O}_{3}-\mathrm{ZrO}_{2}$ calcined in an air atmosphere for $4 \mathrm{~h}$ at $400{ }^{\circ} \mathrm{C}$. 
Furthermore, the phase composition studies of spent $20 \% \mathrm{Ni}$ catalysts supported on $\mathrm{ZrO}_{2}$, $5 \% \mathrm{La}_{2} \mathrm{O}_{3}-\mathrm{ZrO}_{2}$, and $5 \% \mathrm{CeO}_{2}-\mathrm{ZrO}_{2}$ carriers were given in Figure 11 . The results confirm the presence of monoclinic and tetragonal $\mathrm{ZrO}_{2}$ and metallic nickel phases on the diffractions curves. It is also worth emphasizing that the catalytic systems and the average size of the nickel oxide and metallic nickel crystallites were calculated based on the Scherrer's formula which is presented below:

$$
\mathrm{D}=\mathrm{Kl} /(\cos \theta)
$$

where $\mathrm{D}$ is the averaged dimension of the crystallites, $\mathrm{K}$ is the Scherrer constant. In the formula represented above, $\mathrm{K}$ is the wavelength of $\mathrm{X}$-ray $(\mathrm{CuK} \alpha=0.154 \mathrm{~nm})$, and $\mathrm{B}$ is the width of the peak at half height. The results of the calculation performed for the calcined catalysts are given in Table 1. The obtained results show that the lowest crystallites size of $\mathrm{NiO}$ was observed for the $20 \% \mathrm{Ni}-5 \% \mathrm{La}_{2} \mathrm{O}_{3}-\mathrm{ZrO}_{2}$ system, while the largest size of the $\mathrm{NiO}$ crystallites was detected for the $20 \mathrm{Ni} \% \mathrm{ZrO}_{2}$ catalyst (see Figure 10 ).

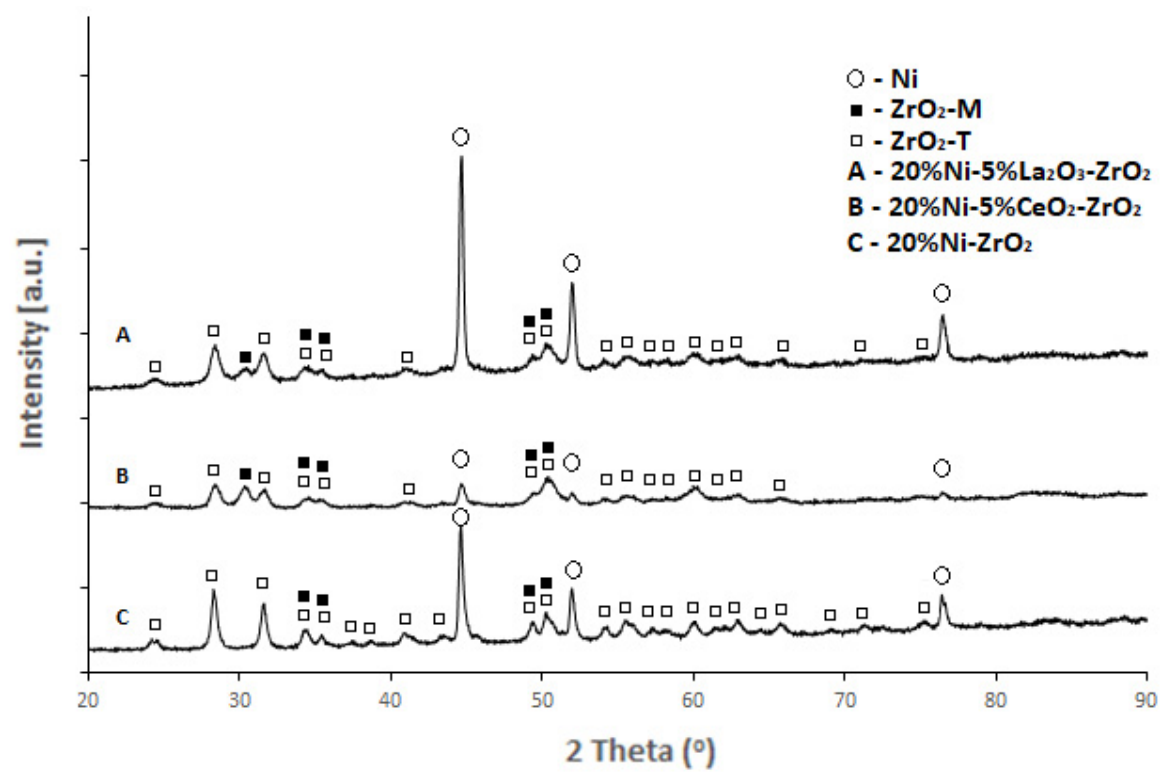

Figure 11. $\mathrm{XRD}$ curves of spent $20 \% \mathrm{Ni}$ catalysts supported on $\mathrm{ZrO} 2,5 \% \mathrm{La}_{2} \mathrm{O}_{3}-\mathrm{ZrO}_{2}$, and $5 \% \mathrm{CeO}_{2}-\mathrm{ZrO}_{2}$ carriers.

Table 1. Size of $\mathrm{NiO}$ crystallites estimated by the Scherrer method for a NiO peak (200) for an angle of 2theta $=43.36^{\circ}$ obtained from XRD measurements performed for Ni catalysts calcined in an air atmosphere at $400{ }^{\circ} \mathrm{C}$ for $4 \mathrm{~h}$.

\begin{tabular}{ccc}
\hline No. & Catalyst & The Size of NiO Crystallites [nm] \\
\hline 1 & $20 \mathrm{Ni}^{2} \mathrm{ZrO}_{2}$ & 32 \\
2 & $20 \% \mathrm{Ni}-5 \% \mathrm{CeO}_{2}-\mathrm{ZrO}_{2}$ & 24 \\
3 & $20 \% \mathrm{Ni}-5 \% \mathrm{La} 2 \mathrm{O} 3-\mathrm{ZrO} 2$ & 20 \\
\hline
\end{tabular}

Afterwards, spent Ni catalysts were tested using the same XRD technique. The X-ray patterns recorded for the Ni systems containing $20 \mathrm{wt} . \%$ of Ni are shown in Figure 11. The obtaining results clearly show the diffraction peaks located at about 2 theta angle $44.5^{\circ}$. The occurrence of these peaks proves the formation of the metallic nickel phase. The profiles fitting for the $\mathrm{Ni}$ (111) peaks were successful and gave average crystallite sizes of metallic $\mathrm{Ni}$ for all investigated catalytic systems, and the obtained results are presented in Table 2. As can be seen, the lowest crystallites of metallic $\mathrm{Ni}$ had the $20 \% \mathrm{Ni} / 5 \% \mathrm{CeO}_{2}-\mathrm{ZrO}_{2}$ catalyst. While the highest crystallites of $\mathrm{Ni}^{\circ}$ particles owned spent the $20 \% \mathrm{Ni} / 5 \% \mathrm{La}_{2} \mathrm{O}_{3}-\mathrm{ZrO}_{2}$ catalyst, which exhibited the lowest catalytic activity in the investigated 
oxy-steam reforming process of LNG. Considering the obtained XRD results, it should be emphasized that only in the case of a catalyst with the addition of $\mathrm{La}_{2} \mathrm{O}_{3}$ is a significant increase in metallic nickel crystallites' size observed after the oxy-steam reforming of LNG.

Table 2. Crystallite size of metallic nickel calculated from XRD measurements performed for spent Ni catalysts (after catalytic tests performed in the oxy-steam reforming of LNG process in the temperature range $400-700{ }^{\circ} \mathrm{C}$, a molar ratio between reagents was used: $\mathrm{C}: \mathrm{H}_{2} \mathrm{O}: \mathrm{O}_{2}=1: 2.7: 0.35$, the total gas flow was $\left.51 \mathrm{~cm}^{3} / \mathrm{min}\right)$.

\begin{tabular}{ccc}
\hline No. & Catalyst & The Size of $\mathbf{N i}^{\circ}$ Crystallites [nm] \\
\hline 1 & $20 \% \mathrm{Ni} / \mathrm{ZrO}_{2}$ & 35 \\
2 & $20 \% \mathrm{Ni} / 5 \% \mathrm{CeO}_{2}-\mathrm{ZrO}_{2}$ & 22 \\
3 & $20 \% \mathrm{Ni} / 5 \% \mathrm{La}_{2} \mathrm{O}_{3}-\mathrm{ZrO}_{2}$ & 41 \\
\hline
\end{tabular}

\subsection{Reducibility Studies of Catalytic Materials}

The reducibility of the Ni catalysts was studied using TPR- $\mathrm{H}_{2}$ method, and the results for $\mathrm{ZrO}_{2}$ oxide and Ni catalysts supported on this carrier are given in Figure 12.

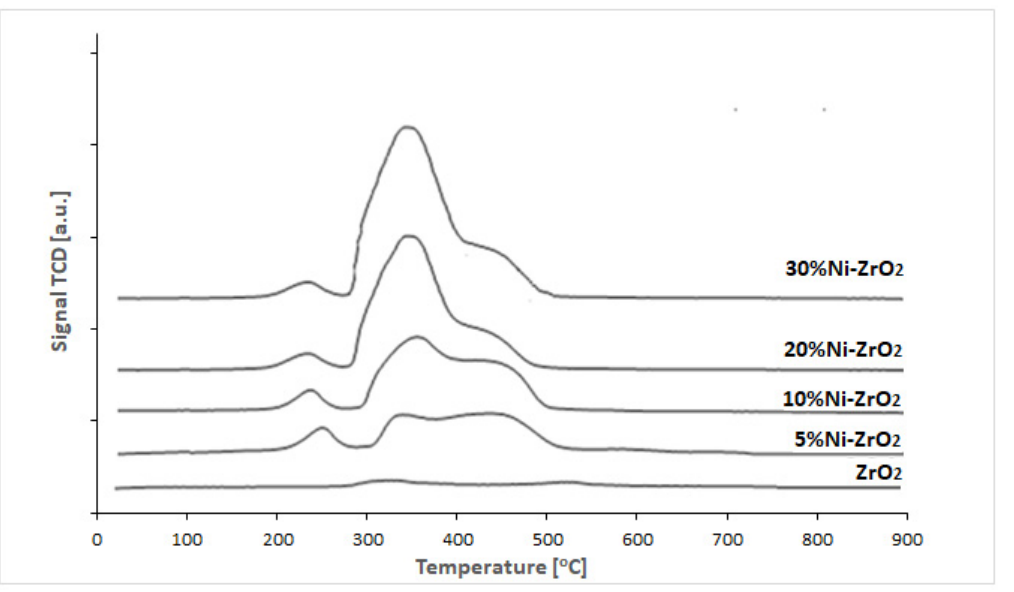

Figure 12. Temperature programmed reduction profiles of $\mathrm{ZrO}_{2}$ and Ni catalysts supported on $\mathrm{ZrO}_{2}$ oxide calcined in an air atmosphere for $4 \mathrm{~h}$ at $400^{\circ} \mathrm{C}$.

TPR-H $\mathrm{H}_{2}$ profile recorded for the carrier itself shows two reduction stages located at about 310 and $520{ }^{\circ} \mathrm{C}$ assigned to the reversible hydrogen uptake of the $\mathrm{ZrO}_{2}$ surface [18,19]. Temperature programmed reduction studies performed for $\mathrm{Ni}$ catalysts confirmed a three-stage reduction process of the Ni systems. The TPR- $\mathrm{H}_{2}$ curve recorded for the $5 \% \mathrm{Ni} / \mathrm{ZrO}_{2}$ catalyst showed three reduction stages. The first effect located at about $230{ }^{\circ} \mathrm{C}$ is assigned to the reduction of free $\mathrm{NiO}$ species located on the support surface. The next two reduction effects located at 320 and $440{ }^{\circ} \mathrm{C}$ are assigned to the reduction of $\mathrm{NiO}$ interacted with support [6]. Similar reduction behavior was observed in the work [20,21]. The increase of the Ni loading in the catalytic systems shifts the reduction stages towards a lower temperature range and an increase in the intensities assigned to the low temperature effects. In the next step, we investigated the influence of $\mathrm{CeO}_{2}$ and $\mathrm{La}_{2} \mathrm{O}_{3}$ oxides addition on the reducibility of the $20 \% \mathrm{Ni}$ catalysts. Figure 13 presents the reduction behavior of the $20 \% \mathrm{Ni}$ catalysts supported on $\mathrm{ZrO}_{2}, 5 \% \mathrm{La}_{2} \mathrm{O}_{3}-\mathrm{ZrO}_{2}$, and $5 \% \mathrm{CeO}_{2}-\mathrm{ZrO}_{2}$ carriers. The presented results clearly show that the addition of $5 \% \mathrm{La}_{2} \mathrm{O}_{3}$ improves the $\mathrm{NiO}$ reduction that is manifested by the increase of the reduction peaks intensity compared to the reduction effects observed in the TPR- $\mathrm{H}_{2}$ profile of the $\mathrm{Ni} / \mathrm{ZrO} 2$ catalyst. In addition, it should be also emphasized that the addition of $\mathrm{La}_{2} \mathrm{O}_{3}$ into the $20 \% \mathrm{Ni} / \mathrm{ZrO} 2$ system caused the increase in the intensity of the reduction stage, with the maximum of the hydrogen consumption peak located at $340{ }^{\circ} \mathrm{C}$. 


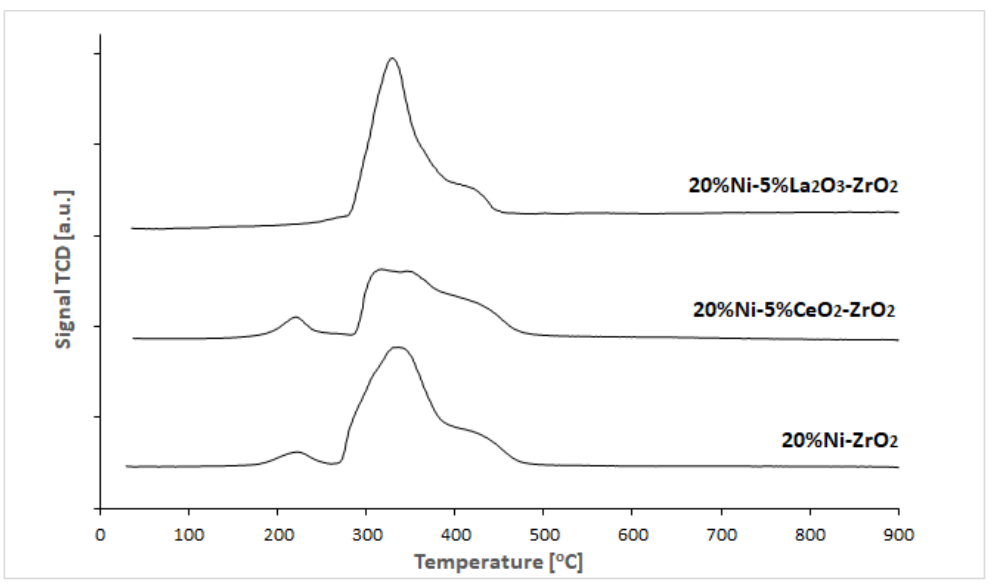

Figure 13. Temperature programmed reduction profiles of $20 \% \mathrm{Ni}$ catalysts supported on $5 \% \mathrm{La}_{2} \mathrm{O}_{3}-\mathrm{ZrO}_{2}$, $5 \% \mathrm{CeO}_{2}-\mathrm{ZrO}_{2}$, and $\mathrm{ZrO}_{2}$ calcined in an air atmosphere for $4 \mathrm{~h}$ at $400{ }^{\circ} \mathrm{C}$.

The influence of the $5 \% \mathrm{CeO}_{2}$ addition on the reduction behavior of $\mathrm{Ni} / \mathrm{ZrO}_{2}$ catalyst is also presented in Figure 13. The reduction profile recorded for the $20 \% \mathrm{Ni} / 5 \% \mathrm{CeO}_{2}-\mathrm{ZrO}_{2}$ system shows the same reduction stages that were observed in the case of the $\mathrm{Ni} / \mathrm{ZrO}_{2}$ system. In addition, the TPR- $\mathrm{H}_{2}$ reduction profile of $20 \% \mathrm{Ni} / 5 \% \mathrm{CeO}_{2}-\mathrm{ZrO}_{2}$ shows the slight shift of the reduction stages towards higher temperature compared to the Ni system supported on $\mathrm{ZrO}_{2}$. This result confirms the stronger interaction between $\mathrm{NiO}$ species and support components [14]. compared to the $20 \% \mathrm{Ni} / \mathrm{ZrO}_{2}$ catalyst. A similar tendency was also observed by Takeguchi and co-workers [14].

In addition, the reduction degree of nickel catalysts was determined based on the hydrogen consumption peaks. An amount of hydrogen consumed during each TPR run was presented in Table 3 . The results clearly show that increasing the $\mathrm{Ni}$ content from 10 to $20 \% \mathrm{wt}$. of $\mathrm{Ni}$ in the investigated catalyst leads to a decrease in the hydrogen consumption for $\mathrm{Ni} / \mathrm{ZrO}_{2}$ catalysts from $99 \%$ to $80 \%$ (see Table 3), while further increasing the Ni content in the catalytic material leads to the degree of reduction equal $71 \%$ estimated for the $30 \% \mathrm{Ni} / \mathrm{ZrO}_{2}$ catalyst. In the case of the catalysts containing $20 \% \mathrm{wt}$. of $\mathrm{Ni}$, the estimated reduction degree values show that the highest hydrogen consumption was achieved using the $20 \% \mathrm{Ni} / 5 \% \mathrm{La}_{2} \mathrm{O}_{3}-\mathrm{ZrO}_{2}\left(3.36 \times 10^{+4} \mathrm{~mol}\right.$ of $\left.\mathrm{H}_{2}\right)$ catalyst. On the other hand, the lowest degree of the reduction value $(60 \%)$ was achieved using the $20 \% \mathrm{Ni} / 5 \% \mathrm{CeO}_{2}-\mathrm{ZrO}_{2}$ supported catalyst. The reduction of $\mathrm{NiO}$ on the catalysts with a high metal loading may be hindered in the case of the strong interaction between $\mathrm{NiO}$ and $\mathrm{ZrO}_{2}$ or $\mathrm{NiO}$ and $\mathrm{CeO}_{2}$. The incomplete reduction confirmed by the reduction degree calculated for the investigated catalysts can be explained by the strong interaction between $\mathrm{NiO}$ and the support component or by the solid solution formation between these species [3].

Table 3. Amount of hydrogen consumed during the TPR run and the estimated reduction degree for the nickel catalysts.

\begin{tabular}{ccc}
\hline Catalysts & $\mathbf{H}_{\mathbf{2}}$ Consumed $\left.\mathbf{( m o l} / \mathbf{g}_{\mathbf{c a t}}\right) \times \mathbf{1 0}^{\mathbf{+ 4}}$ & Reduction of $\mathbf{~ N i O}(\mathbf{\%})$ \\
\hline $5 \% \mathrm{Ni} / \mathrm{ZrO}_{2}$ & 0.84 & 99 \\
$10 \% \mathrm{Ni} / \mathrm{ZrO}_{2}$ & 1.69 & 99 \\
$20 \% \mathrm{Ni}_{2} / \mathrm{ZrO}_{2}$ & 2.70 & 80 \\
$30 \% \mathrm{Ni}_{2} \mathrm{ZrO}_{2}$ & 3.60 & 71 \\
$20 \% \mathrm{Ni} / 5 \% \mathrm{La}_{2} \mathrm{O}_{3}-\mathrm{ZrO}_{2}$ & 3.36 & 99 \\
$20 \% \mathrm{Ni} / 5 \% \mathrm{CeO}_{2}-\mathrm{ZrO}_{2}$ & 2.01 & 60 \\
\hline
\end{tabular}

\subsection{Specific Surface Area Measurements of Supports and Monometallic Nickel Catalysts}

The specific surface area (SSA) measurements performed for $\mathrm{ZrO}_{2}$ and monometallic nickel catalysts are given in Figures 14 and 15 and in Table 4. The obtained results show that the highest specific surface area had a $\mathrm{ZrO}_{2}$ support. The incorporation of the $\mathrm{NiO}$ phase on the catalyst support 
results in decrease in the SSA to $94.4 \mathrm{~m}^{2} / \mathrm{g}$ for the $5 \% \mathrm{Ni} / \mathrm{ZrO}_{2}$ catalyst. A further increase in the $\mathrm{Ni}$ content caused a similar effect. The BET results show that the $10 \% \mathrm{Ni} / \mathrm{ZrO}_{2}, 20 \% \mathrm{Ni} / \mathrm{ZrO}{ }_{2}$, and $30 \% \mathrm{Ni} / \mathrm{ZrO}_{2}$ catalyst exhibited the SSA values equal $85.0,76.8$, and $63.4 \mathrm{~m}^{2} / \mathrm{g}$, respectively. The same effect was also observed for the $\mathrm{ZrO}_{2}$ system promoted by $\mathrm{La}_{2} \mathrm{O}_{3}$ and $\mathrm{CeO}_{2}$ oxides. In the case of the $\mathrm{ZrO}_{2}$ systems promoted by these oxides, a decrease of the specific surface area value was also detected, whereas the catalytic supports $5 \% \mathrm{CeO}_{2}-\mathrm{ZrO}_{2}$ and $5 \% \mathrm{La}_{2} \mathrm{O}_{3}-\mathrm{ZrO}_{2}$ were characterized by the SSA values equal to 98.5 and 92.7, respectively. The same tendency was observed for nickel catalysts supported on the $5 \% \mathrm{CeO}_{2}-\mathrm{ZrO}_{2}$ and $5 \% \mathrm{La}_{2} \mathrm{O}_{3}-\mathrm{ZrO}_{2}$ support material.

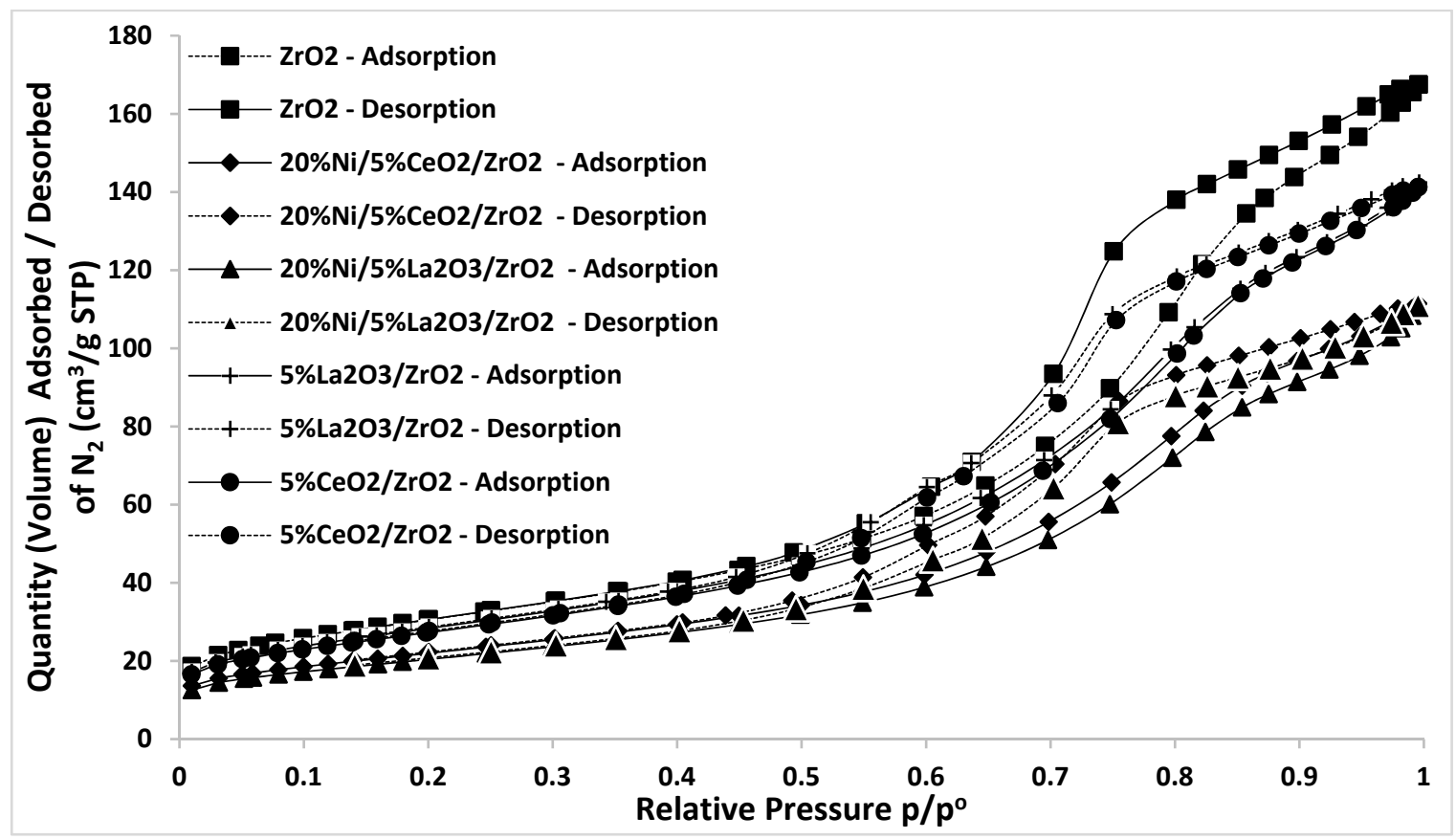

Figure 14. BET adsorption-desorption isotherms for supports and monometallic Ni catalysts calcined in an air atmosphere at $400{ }^{\circ} \mathrm{C}$ for $4 \mathrm{~h}$.

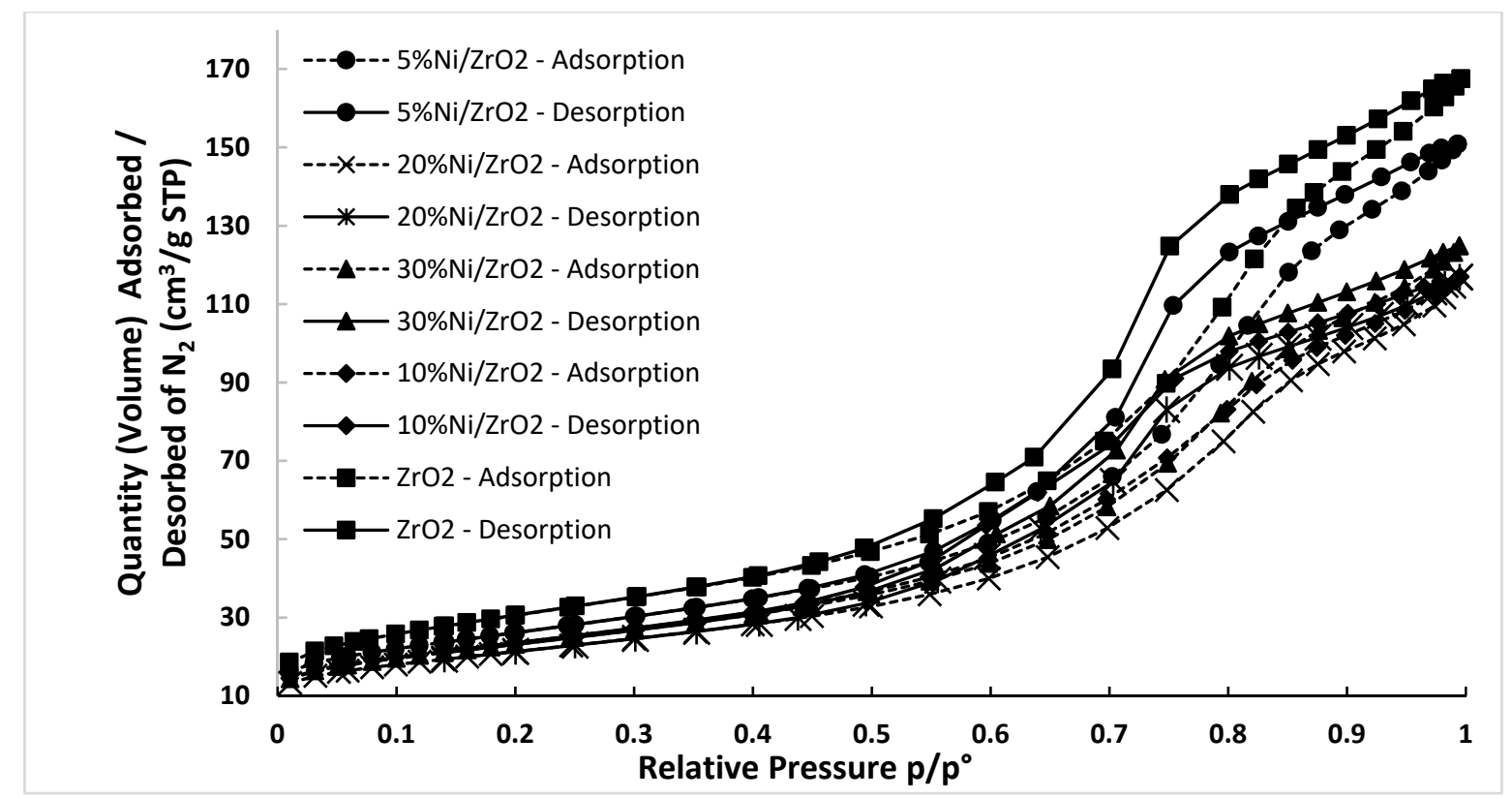

Figure 15. BET adsorption-desorption isotherms for monometallic Ni catalysts calcined in an air atmosphere at $400^{\circ} \mathrm{C}$ for $4 \mathrm{~h}$. 
The average pore radius values for the investigated catalysts were in the range $2.9-3.4 \mathrm{~nm}$ and the monolayer capacity between 0.17 to $0.26 \mathrm{~cm}^{3} / \mathrm{g}$ values. The highest value $(0.26)$ of monolayer capacity was observed for $\mathrm{ZrO}_{2}$ oxide, which owned the highest SSA value equal to $109.6 \mathrm{~m}^{2} / \mathrm{g}$. All the samples in Figures 14 and 15 show the typical type I isotherm (classification by IUPAC [22]) with a hysteresis loop from $\mathrm{p} / \mathrm{p}^{\circ}=0.45$ due to presence of mesopores. Furthermore, the shapes of hysteresis loops according to IUPAC are $\mathrm{H} 1$ type and characteristic for solids consisting of particles crossed by cylindrical channels or made by aggregates (consolidated) or agglomerates (unconsolidated) of spheroidal particles. In both cases, pores can have a uniform size and shape (type H1) [23].

Table 4. Specific surface area and pore size distributions of support and monometallic Ni-supported catalysts calcined in an air atmosphere at $400^{\circ} \mathrm{C}$ for $4 \mathrm{~h}$.

\begin{tabular}{cccc}
\hline Materials & $\begin{array}{c}\text { BET Surface Area } \\
\left(\mathbf{m}^{2} / \mathbf{g}\right)\end{array}$ & $\begin{array}{c}\text { Monolayer Capacity } \\
\left(\mathbf{c m}^{\mathbf{3}} \mathbf{g}\right)\end{array}$ & $\begin{array}{c}\text { Average Pore Radius } \\
(\mathbf{n m})\end{array}$ \\
\hline $\mathrm{ZrO}_{2}$ & 109.6 & 0.26 & 3.4 \\
$5 \% \mathrm{CeO}_{2}-\mathrm{ZrO}_{2}$ & 98.5 & 0.22 & 3.2 \\
$5 \% \mathrm{La}_{2} \mathrm{O}_{3}-\mathrm{ZrO}_{2}$ & 92.7 & 0.21 & 2.9 \\
$5 \% \mathrm{Ni}_{2} / \mathrm{ZrO}_{2}$ & 94.4 & 0.23 & 3.5 \\
$10 \% \mathrm{Ni} / \mathrm{ZrO}_{2}$ & 85.0 & 0.18 & 3.1 \\
$20 \% \mathrm{Ni}_{2} / \mathrm{ZO}_{2}$ & 76.8 & 0.18 & 3.4 \\
$20 \% \mathrm{Ni} / 5 \% \mathrm{CeO}_{2}-\mathrm{ZrO}_{2}$ & 79.4 & 0.17 & 3.2 \\
$20 \% \mathrm{Ni} / 5 \% \mathrm{La}_{2} \mathrm{O}_{3}-\mathrm{ZrO}_{2}$ & 73.6 & 0.17 & 3.4 \\
$30 \% \mathrm{Ni}_{2} / \mathrm{ZO}_{2}$ & 63.4 & 0.17 & 3.2 \\
\hline
\end{tabular}

\subsection{Acidity of the Catalytic Systems}

The acidity properties of support and monometallic Ni catalysts were studied using the TPD-NH technique in order to study their donor-acceptor electron and acid-base properties, and the results are shown in Table 5 and Figures 16-18, respectively. The acidic results clearly show that the lowest total acidity was achieved using the $\mathrm{ZrO}_{2}$ system (see Figure 16). The introduction of Ni by the impregnation method results in an increase in the acidity in the catalytic systems. These results are explained by the increase in the metallic centers that are present on the catalysts surface and play a crucial role during the adsorption of hydrocarbons in the reforming processes. The results of the acidity show that the addition of the $\mathrm{La}_{2} \mathrm{O}_{3}$ or $\mathrm{CeO}_{2}$ oxides into $\mathrm{ZrO}_{2}$ systems caused a similar effect. The $5 \% \mathrm{La}_{2} \mathrm{O}_{3}-\mathrm{ZrO}_{2}$ and $5 \% \mathrm{CeO}_{2}-\mathrm{ZrO}_{2}$ materials exhibited a higher total acidity compared to the $\mathrm{ZrO}$ alone, while $20 \% \mathrm{Ni}$ catalysts supported on the modified $\mathrm{ZrO}_{2}$ carrier exhibited lower total acidity compared to the $5 \% \mathrm{CeO}_{2}-\mathrm{ZrO}_{2}$ and $5 \% \mathrm{La}_{2} \mathrm{O}_{3}-\mathrm{ZrO}_{2}$ supports. This result can be explain by the covering of the acidic sites of the supports by metallic oxide particles introduced on the surface. In addition, the introduction of the $\mathrm{NiO}$ species during the preparation step may generate interactions between $\mathrm{NiO}$ and the support component, which may have an influence on the total acidity of the investigated catalysts. Nickel catalysts $20 \% \mathrm{Ni} / 5 \% \mathrm{La}_{2} \mathrm{O}_{3}-\mathrm{ZrO}{ }_{2}$ and $20 \% \mathrm{Ni} / 5 \% \mathrm{CeO}_{2}-\mathrm{ZrO}_{2}$, which showed higher total acidity compared to the unpromoted catalytic system exhibited lower catalytic activity in the low temperature range. These results may be explained by the stronger adsorption of hydrocarbon molecules on the metallic surface during the process. In this case, adsorptive methane dissociation of light hydrocarbons or methane to carbon monoxide or carbon dioxide is much more difficult. 
Table 5. Amount of $\mathrm{NH}_{3}$ adsorbed on the surface of $\mathrm{ZrO}_{2}$ and the reduced monometallic Ni-supported catalysts (reduction for $1 \mathrm{~h}$ in pure hydrogen at $500{ }^{\circ} \mathrm{C}$ ) calculated from the surface under the peaks recorded during temperature-programmed desorption measurements.

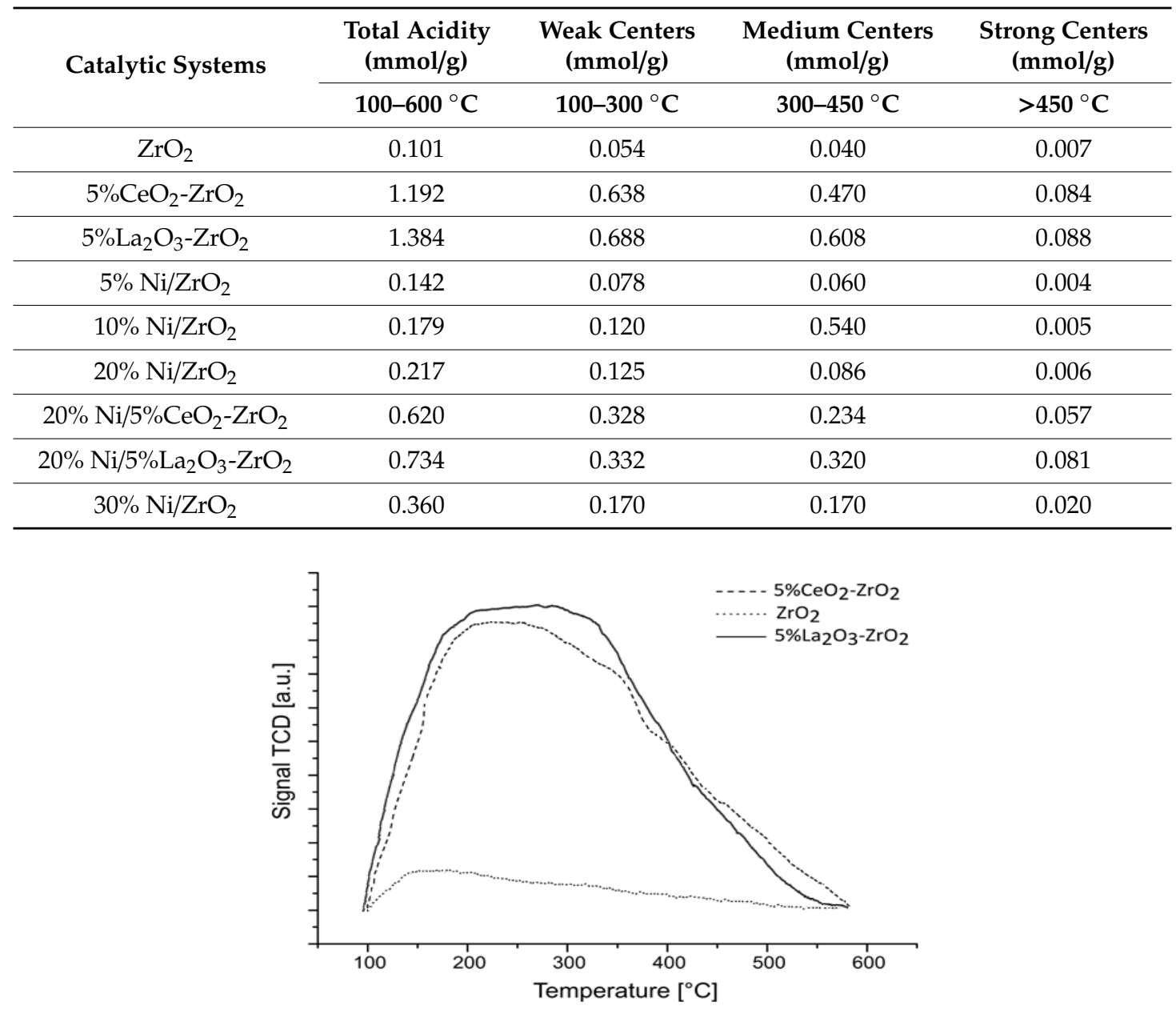

Figure 16. TPD-NH 3 profile of $\mathrm{ZrO}_{2}, 5 \% \mathrm{CeO}_{2}-\mathrm{ZrO}_{2}$, and $5 \% \mathrm{La}_{2} \mathrm{O}_{3}-\mathrm{ZrO}_{2}$ carriers calcined in an air atmosphere for $4 \mathrm{~h}$ at $400{ }^{\circ} \mathrm{C}$.

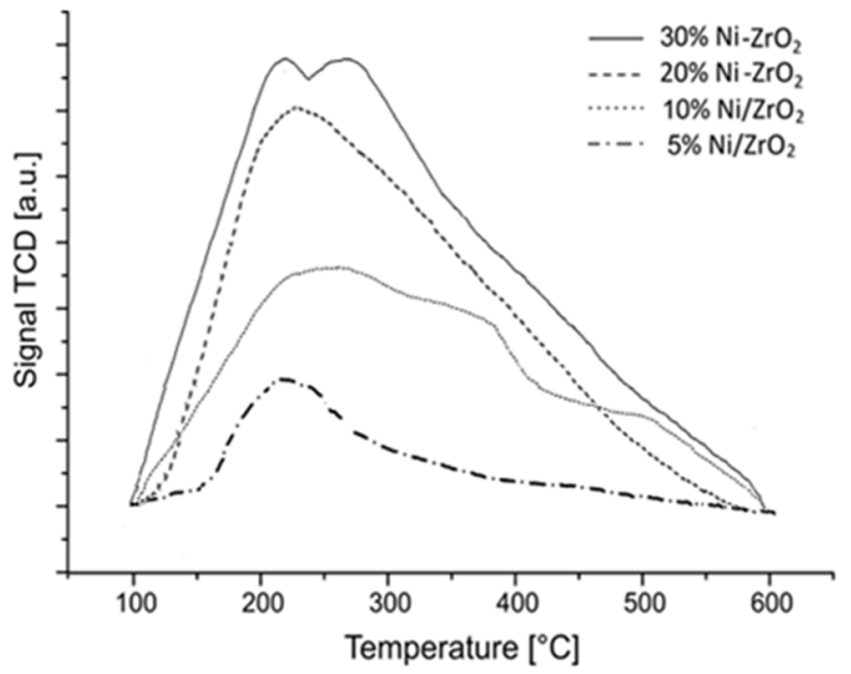

Figure 17. TPD-NH 3 profile of $\mathrm{Ni} / \mathrm{ZrO}_{2}$ catalysts reduced in hydrogen for $1 \mathrm{~h}$ at $500{ }^{\circ} \mathrm{C}$. 


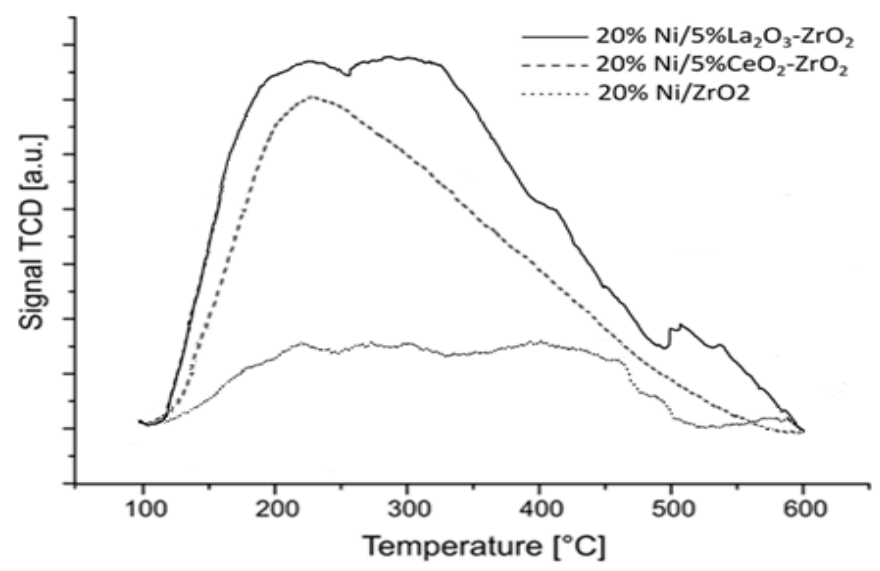

Figure 18. TPD-NH 3 profile of $20 \% \mathrm{Ni} / \mathrm{ZrO} 2,20 \% \mathrm{Ni} / 5 \% \mathrm{CeO}_{2}-\mathrm{ZrO}_{2}$, and $20 \% \mathrm{Ni} / 5 \% \mathrm{La}_{2} \mathrm{O}_{3}-\mathrm{ZrO}_{2}$ catalysts reduced in hydrogen for $1 \mathrm{~h}$ at $500{ }^{\circ} \mathrm{C}$.

\subsection{SEM-EDS Measurements of Monometallic Ni Catalysts}

SEM-EDS measurements of monometallic nickel catalysts supported on $\mathrm{ZrO}_{2}$ monoxide carrier were done, and the results are given in Figure 19. The SEM measurements were done to study the surface morphology of the nickel-supported catalysts. The SEM images obtained for various monometallic Ni catalysts with Ni loading in the range 5-20\% wt. are shown in Figure 19. The results obtained for the various $\mathrm{Ni}$ catalysts show that the $\mathrm{Ni}$ catalyst with 10 and $20 \% \mathrm{wt}$. of $\mathrm{Ni}$ exhibited homogenous distributions of nickel on the catalyst surface, which explains their high activity in the investigated processes. The SEM-EDS measurements performed on the investigated catalysts confirmed the composition of the investigated systems and the absence of impurities derived from the precursor salts used during the preparation of the catalysts.

\subsection{Morphology Studies of the Catalytic Material by the ToF-SIMS Technique}

The chemical composition of the surface of the spent catalysts was investigated using time-of-flight secondary ion mass spectrometry (TOF-SIMS). The secondary ions $\mathrm{Ni}^{+}, \mathrm{NiOH}^{+}, \mathrm{Zr}^{+}, \mathrm{ZrO}^{+}, \mathrm{ZrOH}^{+}$, and $\mathrm{NiZrO}^{+}$emitted from the surface during the TOF-SIMS experiments were chosen as characteristic for the chemical composition of the catalysts' surface. Their emission intensities are presented in Table 6. Qualitative estimation of Ni surface concentration was made using the relative value of the ratio of $\mathrm{Ni}^{+}$to $\mathrm{ZrO}^{+}$ion emission intensity (Table 7). It can be seen that this ratio, as the function of the nominal nickel content of the catalysts, increases faster for $20 \% \mathrm{Ni} / \mathrm{ZrO}_{2}$ and $30 \% \mathrm{Ni} / \mathrm{ZrO}_{2}$ catalysts than for the catalyst with a lower nickel content. This observation can be explained by the fact that the dispersion of nickel on the surface of the $20 \% \mathrm{Ni} / \mathrm{ZrO}_{2}$ and $30 \% \mathrm{Ni} / \mathrm{ZrO}_{2}$ catalysts is higher than for the other catalyst studied.

Table 6. TOF-SIMS results obtained for spent $\mathrm{Ni}$ catalysts supported on $\mathrm{ZrO}_{2}$ oxide.

\begin{tabular}{ccccc}
\hline \multicolumn{5}{c}{$\mathbf{N u m b e r}$ of Counts $\times \mathbf{1 0}^{\mathbf{3}}$} \\
\hline Ion & $\mathbf{5 \%} \mathbf{N i} / \mathbf{Z r O}_{\mathbf{2}}$ & $\mathbf{1 0} \mathbf{0} \mathbf{N i} / \mathbf{Z r O}_{\mathbf{2}}$ & $\mathbf{2 0} \mathbf{0} \mathbf{N i} / \mathbf{Z r O} \mathbf{2}$ & $\mathbf{3 0} \mathbf{\%} \mathbf{N i} / \mathbf{Z r O}_{\mathbf{2}}$ \\
\hline $\mathrm{Ni}^{+}$ & 45.0 & 67.1 & 180.3 & 163.9 \\
$\mathrm{NiOH}^{+}$ & 3.0 & 5.1 & 12.0 & 9.0 \\
$\mathrm{Zr}^{+}$ & 16.2 & 17.4 & 14.5 & 7.1 \\
$\mathrm{ZrO}^{+}$ & 56.5 & 60.3 & 46.6 & 18.4 \\
$\mathrm{ZrOH}^{+}$ & 26.5 & 29.0 & 21.6 & 9.0 \\
$\mathrm{NiZrO}^{+}$ & - & 0.4 & 0.5 & - \\
\hline
\end{tabular}


Table 7. The relation between the intensity of selected ions and the nickel content estimated by TOF-SIMS measurements.

\begin{tabular}{cc}
\hline Catalyst & Ion Ratio Intensities of $\mathbf{~ i}^{+} / \mathrm{ZrO}^{+}$ \\
\hline $5 \% \mathrm{Ni} / \mathrm{ZrO}_{2}$ & 0.78 \\
$10 \% \mathrm{Ni} / \mathrm{ZrO}_{2}$ & 1.11 \\
$20 \% \mathrm{Ni} / \mathrm{ZrO}_{2}$ & 3.87 \\
$30 \% \mathrm{Ni} / \mathrm{ZrO}_{2}$ & 8.90 \\
\hline
\end{tabular}
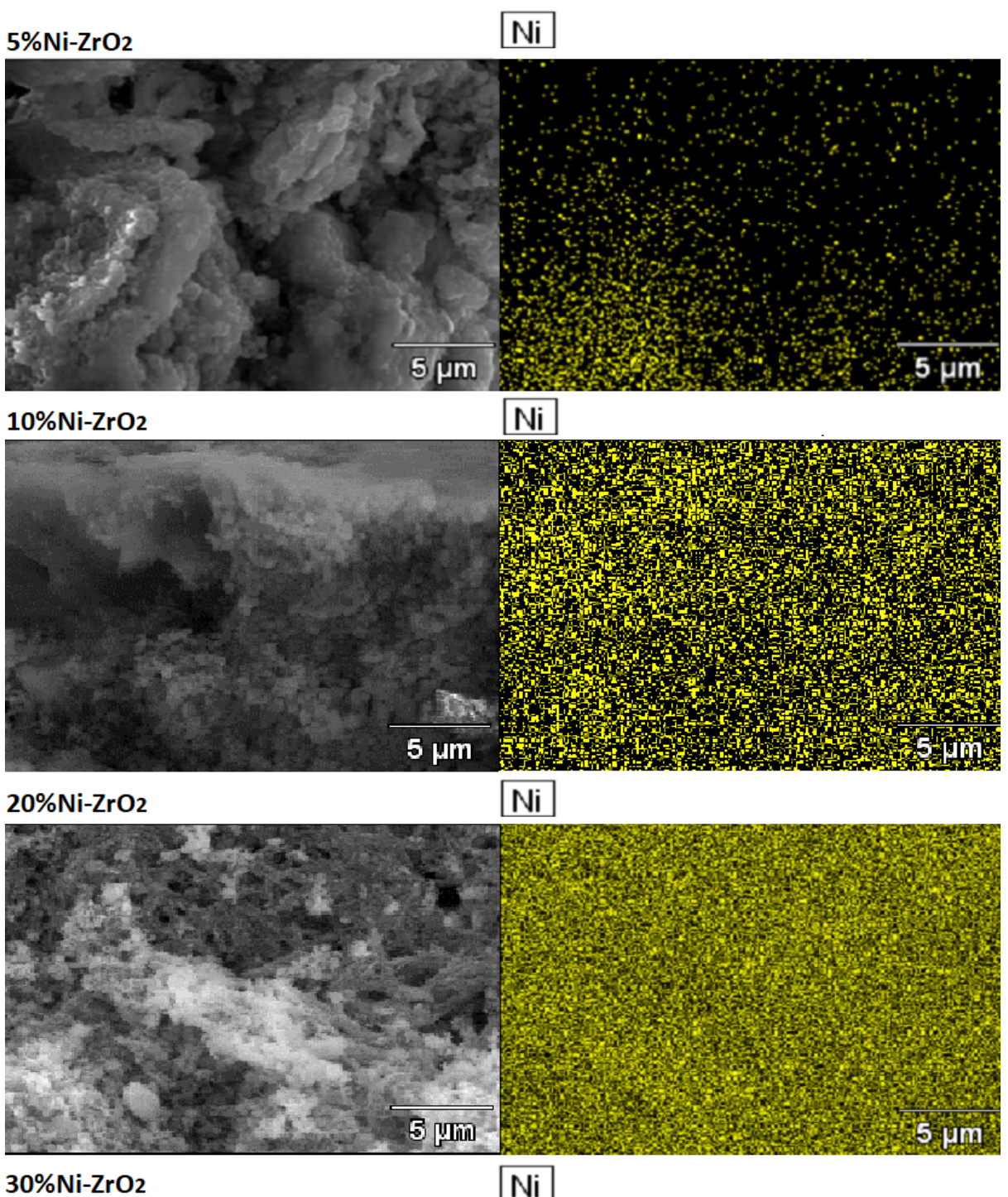

$\mathrm{Ni}$

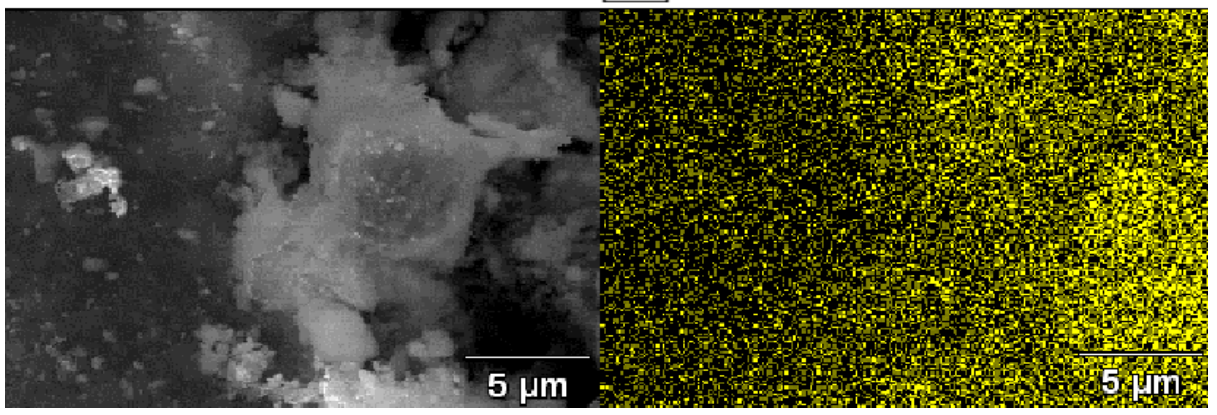

Figure 19. Measurements for monometallic Ni catalysts supported on $\mathrm{ZrO}_{2}$ oxide calcined at $400{ }^{\circ} \mathrm{C}$ in an air atmosphere for $4 \mathrm{~h}$. 
An interesting finding concerns the $\mathrm{NiZrO}^{+}$ions, which are characteristic for the interaction between $\mathrm{Ni}$ species with a catalyst support. The emission of these ions was observed only for the spent $10 \% \mathrm{Ni} / \mathrm{ZrO}_{2}$ and $20 \% \mathrm{Ni} / \mathrm{ZrO}_{2}$ catalysts. $\mathrm{NiZrO}^{+}$ion peak was not observed in TOF-SIMS spectra of the calcined $\mathrm{Ni} / \mathrm{ZrO}_{2}$ catalyst. Therefore, it is reasonable to assume that the high nickel dispersion is not the only factor sufficient to obtain high catalyst activity, but it is also necessary that nickel interacts with the catalyst support to result in the formation of Ni- $\mathrm{Zr}$ intermetallic compounds. In summary, the simultaneous presence of high nickel dispersion and nickel support interaction may explain the high activity of the $20 \% \mathrm{Ni} / \mathrm{ZrO}_{2}$ catalyst. One can expect that such an interaction will also result in a uniform distribution of the nickel phase on the catalyst support. This prediction is confirmed by the result of the EDS analysis (see Figure 19), which showed the most uniform nickel distribution on the surface of the $20 \% \mathrm{Ni} / \mathrm{ZrO}_{2}$ catalyst compared to the rest of the studied systems. In addition, the confirmation of the $\mathrm{NiZrO}^{+}$ions emitted from the surface of the nickel-supported catalysts confirms the interaction between $\mathrm{NiO}$ and $\mathrm{ZrO}_{2}$ and explains the calculated reduction degree for the investigated catalysts.

\subsection{Thermal Analysis of the Spent Catalysts}

The oxy-steam reforming of light hydrocarbons on nickel catalysts involves the risk of coke formation on the catalyst surface, which would lead to its deactivation. Therefore, the resistance to the carbon deposition of the catalysts was investigated in this work. The carbon deposition can be formed during light hydrocarbon decomposition (Equation (1)) or the Boudouard reaction (Equation (2)) [24].

$$
\begin{aligned}
\mathrm{C}_{\mathrm{x}} \mathrm{H}_{\mathrm{y}} & \rightarrow \mathrm{xC}+\mathrm{y} / 2 \mathrm{H}_{2} \\
2 \mathrm{CO} & \rightarrow \mathrm{C}+\mathrm{CO}_{2}
\end{aligned}
$$

At a higher temperature, the decomposition of hydrocarbons is mostly favorable because this reaction is faster than carbon oxide's decomposition or its reduction [24]. The adsorption of hydrocarbons on the catalyst surface leads to the accumulation of the hydrocarbons on the catalyst surface, causing them to transform into an amorphous carbon at low temperature (below $500{ }^{\circ} \mathrm{C}$ ). On the other hand, at a high temperature, the main type of carbon is graphite carbon ( $\mathrm{C} \gamma$ created on the catalyst surface. In this work the carbon deposition was also investigated using a TG-DTA-MS technique. In Figure 20, the MS profiles for $\mathrm{m} / \mathrm{z}=44\left(\mathrm{CO}_{2}\right)$ obtained during the thermal analysis performed in an air atmosphere using spent $\mathrm{Ni}$ catalysts in the temperature range $25-700{ }^{\circ} \mathrm{C}$ were presented. As is easily seen, the oxidation of carbon formed on the catalyst surface occurs in three stages for the $20 \% \mathrm{Ni} / \mathrm{ZrO}_{2}$ catalyst. The oxidation proceeds up to $700{ }^{\circ} \mathrm{C}$ (Figure 20). The peak of $\mathrm{CO}_{2}$ formation, with the maximum at $130^{\circ} \mathrm{C}$ (see MS profile), is really oxidizable of carbon type and may be assigned to the removal of amorphous carbon $[25,26]$. The second oxidation step $\left(310^{\circ} \mathrm{C}\right)$ is attributed to the oligomerized carbon species, which is signed as $B$ carbon $(\mathrm{CB})$ or carbides. The last peak situated at about $690{ }^{\circ} \mathrm{C}$ is assigned to the oxidation of graphite carbon ( $\mathrm{C} \gamma$ bulk carbides $\left.[27,28]\right)$. In the case of $20 \% \mathrm{Ni} / 5 \% \mathrm{La}_{2} \mathrm{O}_{3}-\mathrm{ZrO}_{2}$, the two peaks of carbon oxidation and for the $20 \% \mathrm{Ni} / 5 \% \mathrm{CeO}_{2}-\mathrm{ZrO}_{2}$ catalyst's (Figure 20) three peaks of $\mathrm{CO}_{2}$ formation on the MS profiles are observed. In all studied cases, the type of carbon deposition with maximum at ca. $290^{\circ} \mathrm{C}$ for the catalyst doped by lanthanum oxide and at ca. $310^{\circ} \mathrm{C}$ and second peak with maximum $410{ }^{\circ} \mathrm{C}$ for the catalyst with cerium oxide addition are related to the removal of amorphous carbon and/or oligomerized carbon, while the third peak with maximum at $690^{\circ} \mathrm{C}$ for both catalysts can be assigned to the oxidation of graphite carbon (C $\gamma$ or bulk carbides). It is worth mentioning that the main type of carbon deposition in the all cases studied is graphite carbon $(\mathrm{C} \gamma)$ or bulk carbides. It is also worth mentioning that the addition of $\mathrm{CeO}_{2}$ into the monometallic $\mathrm{Ni} / \mathrm{ZrO}_{2}$ system reduces the carbon deposit formation on the catalyst surface. This result is very important from the application point of view of these systems on an industrial scale. This result can be explained by the presence of mobile oxygen, which can oxidize the carbon deposit or methane absorbed on the surface of metallic nickel during the investigated processes. This mobile oxygen protects the surface of the catalyst against carbon deposits that can be formed during the process. The 
TG-DTA-MS results means that the $20 \% \mathrm{Ni} / \mathrm{ZrO}{ }_{2}$ and $20 \% \mathrm{Ni} / 5 \% \mathrm{CeO}_{2}-\mathrm{ZrO}_{2}$ catalysts, which exhibited practically similar high activity, also showed high coke resistance, while the least active system in the oxy-steam reforming of LNG $\left(20 \% \mathrm{Ni} / 5 \% \mathrm{La}_{2} \mathrm{O}_{3}-\mathrm{ZrO}_{2}\right)$ exhibited the highest amount of carbon deposit formed on its surface (see Figure 20).

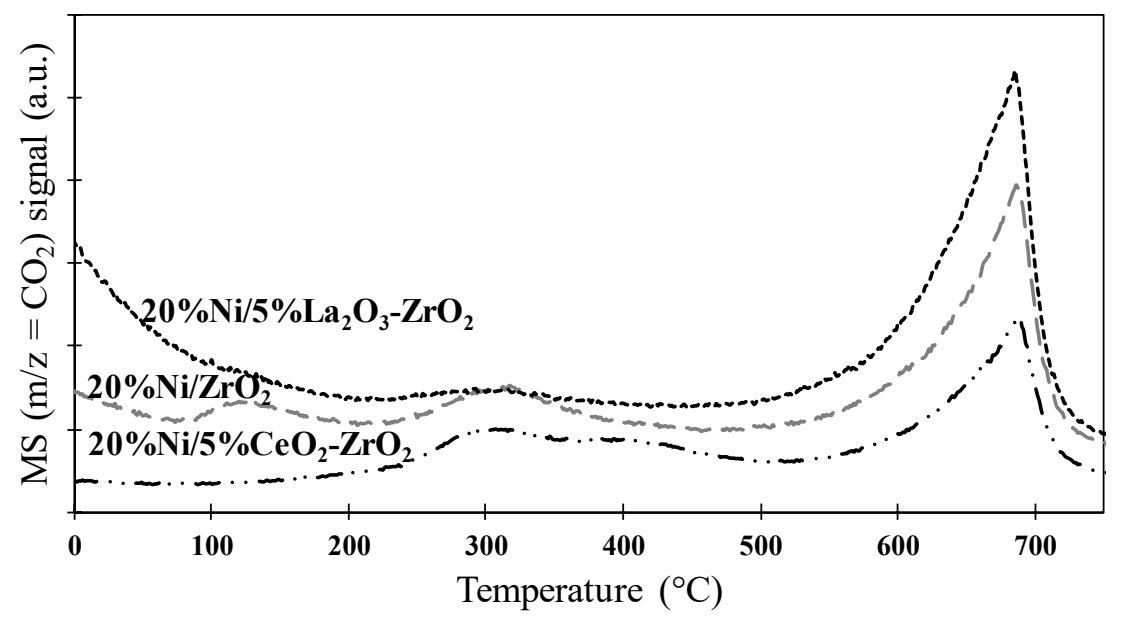

Figure 20. MS profiles for $\mathrm{m} / \mathrm{z}=44\left(\mathrm{CO}_{2}\right)$ obtained during the thermal analysis performed in an air atmosphere of the spent (after twelve hours of the oxy-steam reforming of LNG process at $700{ }^{\circ} \mathrm{C}$, molar ratio between reagents was used: $\mathrm{C}: \mathrm{H}_{2} \mathrm{O}: \mathrm{O}_{2}=1: 2.7: 0.35$, total gas flow $51 \mathrm{~cm}^{3} / \mathrm{min}$ ) monometallic Ni catalysts supported on $\mathrm{ZrO}_{2}, 5 \% \mathrm{CeO}_{2}-\mathrm{ZrO}_{2}$, or $5 \% \mathrm{La}_{2} \mathrm{O}_{3}-\mathrm{ZrO}_{2}$ oxides supports.

\section{Experimental}

\subsection{Supports and Catalysts Preparation}

$\mathrm{ZrO}_{2}$ was synthesized by the precipitation method using ammonia as a precipitation agent. The obtained hydroxide of $\mathrm{Zr}$ was then filtrated, washed with deionized water, and dried in an air atmosphere at $120{ }^{\circ} \mathrm{C}$ for $2 \mathrm{~h}$. The $\mathrm{ZrO}_{2}$ support modified by $5 \% \mathrm{CeO}_{2}$ or $5 \% \mathrm{La}_{2} \mathrm{O}_{3}$ were prepared via impregnation method of previously prepared zirconium oxide. The monometallic nickel catalysts supported on the $\mathrm{ZrO}_{2}, 5 \% \mathrm{CeO}_{2}-\mathrm{ZrO}_{2}$, or $5 \% \mathrm{La}_{2} \mathrm{O}_{3}-\mathrm{ZrO}_{2}$ were prepared using the conventional impregnation method. The $\mathrm{NiO}$ oxide was introduced on the catalyst surface using $\mathrm{Ni}\left(\mathrm{NO}_{3}\right)_{2} \cdot 6 \mathrm{H}_{2} \mathrm{O}$ precursor salt. The support materials were impregnated in $12 \mathrm{~h}$. Then, the catalytic materials were dried for $2 \mathrm{~h}$ at $80^{\circ} \mathrm{C}$ in an air atmosphere and calcined in an air atmosphere for $4 \mathrm{~h}$ at $400{ }^{\circ} \mathrm{C}$. The Ni content in the catalytic systems were $5,10,20$, and $30 \% \mathrm{wt}$, respectively.

\subsection{Characterization of the Catalytic Material}

The BET surface area and porosity of the prepared catalytic systems were determined using ASAP 2020 Micrometrics (Surface Area and Porosity Analyzer, Micromeritics Instrument Corporation, Norcross, GA, USA). The morphology of the prepared catalytic systems was studied using a S-4700 scanning electron microscope HITACHI (Tokyo, Japan), equipped with an energy dispersive spectrometer EDS (ThermoNoran, Madison, WI, USA). The reducibility of the Ni catalysts was investigated using an automatic AMI-1 instrument in the temperature range $25-900{ }^{\circ} \mathrm{C}$. In each TPR investigation, about $0.1 \mathrm{~g}$ of the sample was used. The acidic properties of the catalytic materials reduced at $500{ }^{\circ} \mathrm{C}$ in a mixture of $5 \% \mathrm{H}_{2}-95 \%$ Ar were studied by TPD- $\mathrm{NH}_{3}$ technique. The phase composition studies of the monometallic nickel-supported catalysts after reduction were carried out using a PANalytical X'Peert Pro MPD diffractometer in Bragg-Brentano reflecting geometry. The carbon deposit formed during the oxy-steam reforming of the $\mathrm{CH}_{4}$ or LNG process on the catalyst surface was determined using the TG-DTA-MS technique. Thermal analysis was carried out for spent catalytic material on the SETSYS 16/18 thermal analyzer from Setaram (Caluire, France) and quadrupole mass 
spectrometer Balzers (Germany). The TG-DTA-MS measurements were performed in the temperature range of $30-1000{ }^{\circ} \mathrm{C}$ using a linear temperature rate of $10^{\circ} \mathrm{C} / \mathrm{min}$ using about $10-20 \mathrm{mg}$ in dynamic conditions gas stream-Air (Air Products). The secondary ion mass spectra for the catalytic materials were recorded using a TOF-SIMS IV mass spectrometer manufactured by Ion-Tof GmbH, Muenster, Germany. The instrument is equipped with a Bi liquid metal ion gun and a high mass resolution time of flight mass analyzer.

\subsection{Catalytic Activity Measurements in the Oxy-Steam Reforming of Methane or LNG}

The oxy-steam reforming of LNG (a mixture of methane $(5 \%)$, ethane $(0.4 \%)$, propane $(0.2 \%)$, and butane $(0.05 \%)$ ) or methane was performed in a quartz micro-reactor in the temperature range 400-900 ${ }^{\circ} \mathrm{C}$ under atmospheric pressure. Catalytic activity was measured after reaching a stable state of the catalyst system after $30 \mathrm{~min}$ of the process. The weight of a catalyst test sample was $0.2 \mathrm{~g}$ in all cases. A volumetric ratio between each components of the reaction mixture was as follows: $\mathrm{CH}_{4}: \mathrm{H}_{2} \mathrm{O}$ : $\mathrm{O}_{2}=1: 2.7: 0.35$. Argon was used as a balance gas. In the case of the oxy-steam reforming of LNG, the following molar ratio between reagents was used: $\mathrm{C}: \mathrm{H}_{2} \mathrm{O}: \mathrm{O}_{2}=1: 2.7: 0.35$. While the total gas flow rate of the reaction mixture was $51 \mathrm{~cm}^{3} / \mathrm{min}$. The analysis of the gaseous reaction mixture composition before and after the reaction was monitored using gas chromatographs equipped with TCD and FID detectors. The catalytic activity results were expressed as $\mathrm{CH}_{4}$ or higher hydrocarbons conversions were calculated based on the following equation:

$$
\text { Con. } C_{x} H_{Y}=\left(1-\frac{\left(n_{C_{x} H_{y}}\right)_{\text {out }}}{\left(n_{C_{x} H_{y}}\right)_{\text {in }}}\right) \times 100 \%
$$

The selectivity's to $\mathrm{CO}$ or $\mathrm{CO}_{2}$ were calculated based on the equations presented below:

$$
\begin{gathered}
S_{\mathrm{CO}}=\frac{\left(n_{\mathrm{CO}}\right)_{\text {out }}}{\left(n_{\mathrm{CO}}\right)_{\text {out }}+\left(n_{\mathrm{CO}_{2}}\right)_{\text {out }}} \\
S_{\mathrm{CO}_{2}}=\frac{\left(n_{\mathrm{CO}_{2}}\right)_{\text {out }}}{\left(n_{\mathrm{CO}}\right)_{\text {out }}+\left(n_{\mathrm{CO}_{2}}\right)_{\text {out }}}
\end{gathered}
$$

The hydrogen yield was estimated using the following formula:

$$
\begin{aligned}
& Y_{\mathrm{H}_{2}}=\left(\frac{\frac{\left(\mathrm{n}_{\mathrm{H}_{2}}\right)_{\text {out }}}{2.5}}{\sum\left(\mathrm{n}_{\mathrm{CH}_{4}}\right)_{\mathrm{in}}-\sum\left(\mathrm{n}_{\left.\mathrm{CH}_{4}\right)_{\text {out }}}\right)}\right. \text { (in the case of the oxy-steam reforming of methane) }
\end{aligned}
$$

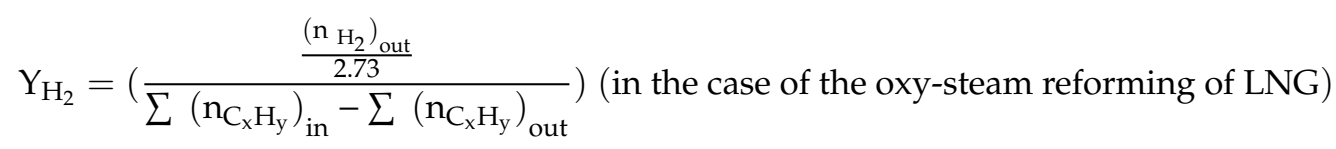

where:

$\left(n_{C_{x} H_{y}}\right)_{\text {out }}$-is the mole fraction of hydrocarbon (methane, ethane, propane and butane) at the reactor entrance;

$\left(n_{C_{x} H_{y}}\right)_{\text {out }}$-is the mole fraction of hydrocarbon (methane, ethane, propane and butane) at the reactor outlet;

$\left(n_{\mathrm{CO}}\right)_{\text {out }}$-is the mole fraction of the $\mathrm{CO}$ at the reactor outlet;

$\left(n \mathrm{CO}_{2}\right)_{\text {out }}$-is the mole fraction of the $\mathrm{CO}_{2}$ at the reactor outlet;

$n_{\mathrm{H}_{2}}$-is the mole fraction of the $\mathrm{H}_{2}$ at the reactor outlet;

$\sum\left(n_{C_{x} H_{y}}\right)_{i n}$-is the sum of the mole fractions of the hydrocarbons at the reactor entrance;

$\sum\left(n_{C_{x} H_{y}}\right)_{\text {out }}$-is the sum of the mole fractions of the hydrocarbons at the reactor outlet. 


\section{Conclusions}

All tested catalysts showed high activity in the temperature range $700-900{ }^{\circ} \mathrm{C}$, but superior activity among of catalytic systems were achieved using $20 \% \mathrm{Ni} / \mathrm{ZrO}$ and $20 \% \mathrm{Ni} / \mathrm{CeO}_{2}-\mathrm{ZrO}_{2}$ catalysts. The $20 \% \mathrm{Ni} / \mathrm{ZrO}_{2}$ catalyst exhibited above $97 \%$ of methane or LNG components conversion at 700 and $100 \%$ at $900^{\circ} \mathrm{C}$. The hydrogen yield for this system in the oxy-steam reforming of methane was more than $88 \%$ at both temperatures. The results in the oxy-steam reforming of methane reaction also show that the molar ratio between products of $\mathrm{H}_{2}$ and $\mathrm{CO}$ at 700 and $900{ }^{\circ} \mathrm{C}$ was equal 2.0 and 2.2 what confirm that produced gas mixture is suitable to generate hydrocarbons via Fischer-Tropsch synthesis. On the other hand, in the case of the oxy-steam reforming of LNG the molar ratio between $\mathrm{H}_{2}$ and CO was 3.5, 2.0, 1.3 at 600,700 and $900^{\circ} \mathrm{C}$, while in the oxy-steam reforming of LNG, the hydrogen yield was 58,74 , 57 , and 63 at $500,600,700$, and $900{ }^{\circ} \mathrm{C}$, respectively. It is also worth mentioning that a similar activity in the oxy-steam reforming of the LNG reaction was achieved using $20 \% \mathrm{Ni} / \mathrm{CeO}_{2}-\mathrm{ZrO}_{2}$, which also exhibited a high hydrogen yield at $700{ }^{\circ} \mathrm{C}(60 \%)$ and the highest hydrogen production at $900{ }^{\circ} \mathrm{C}(58 \%)$. In addition, this system also showed high stability during the 12-h running time of the reaction. The reduction behavior confirmed the incomplete reduction of $\mathrm{NiO}$ in the case of the $20 \% \mathrm{Ni} / \mathrm{CeO}_{2}-\mathrm{ZrO} 2$ catalyst, which is the result of the solid solution formation and strong interaction between $\mathrm{NiO}$ and the support component. In addition, it was also proven that the addition of $\mathrm{CeO}_{2}$ on the surface of $\mathrm{ZrO}_{2}$ leads to the creation of a smaller size of crystallites of $\mathrm{NiO}$ and metallic nickel on the catalyst surface. TG-DTA-MS measurements performed for the catalytic systems proved that the addition of $\mathrm{CeO}_{2}$ increases the resistance to carbon deposition, which can be explained by the increased mobility of oxygen that can oxidize the carbon deposit or methane absorbed on the surface of metallic nickel during the investigated processes and thus protects the surface of the catalyst against carbon deposits. In the case of the $20 \% \mathrm{Ni} / 5 \% \mathrm{La}_{2} \mathrm{O}_{3}-\mathrm{ZrO}_{2}$ catalyst, the highest carbon deposit was formed on its surface during the process performed during $12 \mathrm{~h}$ at $700{ }^{\circ} \mathrm{C}$, which can explain the lowest activity of this systems compared to the rest of the investigated systems. The high activity of the $20 \% \mathrm{Ni} / \mathrm{ZrO}$ catalyst among all of the tested monometallic catalysts is explained by the strong interaction between $\mathrm{NiO}$ and $\mathrm{ZrO}_{2}$, which were confirmed by the TPR measurements and by the detected ToF-SIMS NiZrO' ${ }^{+}$ions created on the catalyst surface for this system.

Author Contributions: The results presented in the work were designed and presented by N.S., M.M., M.N., J.R., J.A., K.C., W.M., M.I.S. and P.M. All authors have read and agreed to the published version of the manuscript.

Funding: The work was funded by the National Science Centre within the "OPUS" Programme, Poland (Grant no. 2018/29/B/ST8/01317).

Conflicts of Interest: The authors declare no conflict of interest.

\section{References}

1. Mierczynski, P.; Vasilev, K.; Mierczynska, A.; Maniukiewicz, W.; Szynkowska, M.I.; Maniecki, T. Bimetallic $\mathrm{Au}-\mathrm{Cu}, \mathrm{Au}-\mathrm{Ni}$ catalysts supported on MWCNTs for oxy-steam reforming of methanol. Appl. Catal. B Environ. 2016, 185, 281-294. [CrossRef]

2. Mierczynski, P.; Mosinska, M.; Maniukiewicz, W.; Nowosielska, M.; Czylkowska, A.; Szynkowska, M.I. Oxy-steam reforming of methanol on copper catalysts. React. Kinet. Mech. Catal. 2019, 127, 857-874. [CrossRef]

3. Mierczynski, P. Comparative Studies of Bimetallic $\mathrm{Ru}-\mathrm{Cu}, \mathrm{Rh}-\mathrm{Cu}, \mathrm{Ag}-\mathrm{Cu}, \mathrm{Ir}-\mathrm{Cu}$ Catalysts Supported on $\mathrm{ZnO}-\mathrm{Al}_{2} \mathrm{O}_{3}, \mathrm{ZrO}_{2}-\mathrm{Al}_{2} \mathrm{O}_{3}$ Systems. Catal. Lett. 2016, 146, 1825-1837. [CrossRef]

4. Mierczynski, P.; Vasilev, K.; Mierczynska, A.; Maniukiewicz, W.; Ciesielski, R.; Rogowski, J.; Szynkowska, M.I.; Trifonov, A.Y.; Dubkov, S.V.; Gromov, D.G.; et al. The effect of gold on modern bimetallic Au-Cu/MWCNT catalysts for the oxy-steam reforming of methanol. Catal. Sci. Technol. 2016, 6, 4168-4183. [CrossRef]

5. Mierczynski, P.; Vasilev, K.; Mierczynska, A.; Maniukiewicz, W.; Maniecki, T. Highly selective Pd-Cu/ZnAl $\mathrm{O}_{4}$ catalyst for hydrogen production. Appl. Catal. A Gen. 2014, 479, 26-34. [CrossRef] 
6. Bang, Y.; Park, S.; Han, S.J.; Yoo, J.; Song, J.H.; Choi, J.H.; Kang, K.H.; Song, I.K. Hydrogen production by steam reforming of liquefied natural gas (LNG) over mesoporous $\mathrm{Ni} / \mathrm{Al}_{2} \mathrm{O}_{3}$ catalyst prepared by an EDTA-assisted impregnation method. Appl. Catal. B: Environ. 2016, 180, 179-188. [CrossRef]

7. Bang, Y.; Han, S.J.; Yoo, J.; Choi, J.H.; Lee, J.K.; Song, J.H.; Lee, J.; Song, I.K. Hydrogen production by steam reforming of simulated liquefied natural gas (LNG) over nickel catalyst supported on mesoporous phosphorus-modified alumina xerogel. Appl. Catal. B: Environ. 2014, 148, 269-280. [CrossRef]

8. Park, S.; Yoo, J.; Han, S.J.; Song, J.H.; Lee, E.J.; Song, I.K. Steam reforming of liquefied natural gas (LNG) for hydrogen production over nickel-boron-alumina xerogel catalyst. Int. J. Hydrogen Energy 2017, 42, 15096-15106. [CrossRef]

9. Gil Seo, J.; Youn, M.H.; Park, S.; Chung, J.S.; Song, I.K. Hydrogen production by steam reforming of liquefied natural gas (LNG) over $\mathrm{Ni} / \mathrm{Al}_{2} \mathrm{O}_{3}-\mathrm{ZrO}_{2}$ xerogel catalysts: Effect of calcination temperature of $\mathrm{Al}_{2} \mathrm{O}_{3}-\mathrm{ZrO}_{2}$ xerogel supports. Int. J. Hydrogen Energy 2009, 34, 3755-3763.

10. Li, K.; Chang, X.; Pei, C.; Li, X.; Chen, S.; Zhang, X.; Assabumrungrat, S.; Zhao, Z.-J.; Zeng, L.; Gong, J. Ordered mesoporous $\mathrm{Ni} / \mathrm{La}_{2} \mathrm{O}_{3}$ catalysts with interfacial synergism towards $\mathrm{CO}_{2}$ activation in dry reforming of methane. Appl. Catal. B: Environ. 2019, 259, 118092. [CrossRef]

11. Maniecki, T.; Stadnichenko, A.I.; Maniukiewicz, W.; Bawolak, K.; Mierczynski, P.; Boronin, A.I.; Jozwiak, W.K. An active phase transformation on surface of $\mathrm{Ni}-\mathrm{Au} / \mathrm{Al}_{2} \mathrm{O}_{3}$ catalyst during partial oxidation of methane to synthesis gas. Kinet. Catal. 2010, 51, 573-578. [CrossRef]

12. Dantas, S.C.; Escritori, J.C.; Soares, R.R.; Hori, C.E. Effect of different promoters on $\mathrm{Ni} / \mathrm{CeZrO}_{2}$ catalyst for autothermal reforming and partial oxidation of methane. Chem. Eng. J. 2010, 156, 380-387. [CrossRef]

13. Wu, H.; Pantaleo, G.; La Parola, V.; Venezia, A.M.; Collard, X.; Aprile, C.; Liotta, L.; Liotta, L. Bi- and trimetallic Ni catalysts over $\mathrm{Al} 2 \mathrm{O} 3$ and $\mathrm{Al}_{2} \mathrm{O}_{3}-\mathrm{MOx}(\mathrm{M}=\mathrm{Ce}$ or $\mathrm{Mg}$ ) oxides for methane dry reforming: $\mathrm{Au}$ and Pt additive effects. Appl. Catal. B: Environ. 2014, 156, 350-361. [CrossRef]

14. Takeguchi, T.; Furukawa, S.-N.; Inoue, M.; Eguchi, K. Autothermal reforming of methane over Ni catalysts supported over $\mathrm{CaO}-\mathrm{CeO}_{2}-\mathrm{ZrO}_{2}$ solid solution. Appl. Catal. A: Gen. 2003, 240, 223-233. [CrossRef]

15. Bachiller-Baeza, B.; Mateos-Pedrero, C.; Soria, M.A.; Guerrero-Ruiz, A.; Rodemerck, U.; Rodríguez-Ramos, I. Transient studies of low-temperature dry reforming of methane over $\mathrm{Ni}-\mathrm{CaO} / \mathrm{ZrO}_{2}-\mathrm{La}_{2} \mathrm{O}_{3}$. Appl. Catal. B: Environ. 2013, 129, 450-459. [CrossRef]

16. Pantaleo, G.; La Parola, V.; Deganello, A.F.; Calatozzo, P.; Bal, R.; Venezia, A.M. Synthesis and support composition effects on $\mathrm{CH}_{4}$ partial oxidation over Ni-CeLa oxides. Appl. Catal. B: Environ. 2015, 164, 135-143. [CrossRef]

17. Галанов, С.И.; Sidorova, O.I. Effect of a precursor on the phase composition and particle size of the active component of $\mathrm{Ni}-\mathrm{ZrO} 2$ catalytic systems for the oxidation of methane into syngas. Russ. J. Phys. Chem. A 2014, 88, 1629-1636. [CrossRef]

18. Hoang, D.L.; Lieske, H. Effect of hydrogen treatments on $\mathrm{ZrO} 2$ and $\mathrm{Pt} / \mathrm{ZrO} 2$ catalysts. Catal. Lett. 1994, 27, 33-42. [CrossRef]

19. Rhodes, M.D.; Pokrovski, K.A.; Bell, A.T. The effects of zirconia morphology on methanol synthesis from $\mathrm{CO}$ and $\mathrm{H}_{2}$ over $\mathrm{Cu} / \mathrm{ZrO}_{2}$ catalystsPart II. Transient-response infrared studies. J. Catal. 2005, 233, 210-220. [CrossRef]

20. Jia, X.; Zhang, X.; Rui, N.; Hu, X.; Liu, C.-J. Structural effect of $\mathrm{Ni} / \mathrm{ZrO}_{2}$ catalyst on $\mathrm{CO}_{2}$ methanation with enhanced activity. Appl. Catal. B: Environ. 2019, 244, 159-169. [CrossRef]

21. Nichele, V.; Signoretto, M.; Pinna, F.; Menegazzo, F.; Rossetti, I.; Cruciani, G.; Cerrato, G.; Di Michele, A. $\mathrm{Ni} / \mathrm{ZrO}_{2}$ catalysts in ethanol steam reforming: Inhibition of coke formation by CaO-doping. Appl. Catal. B: Environ. 2014, 150, 12-20. [CrossRef]

22. Cranston, R.; Inkley, F. 17 The Determination of Pore Structures from Nitrogen Adsorption Isotherms. Advances in Catalysis 1957, 9, 143-154.

23. Leofanti, G.; Padovan, M.; Tozzola, G.; Venturelli, B. Surface area and pore texture of catalysts. Catal. Today 1998, 41, 207-219. [CrossRef]

24. Roh, H.-S.; Jun, K.-W. Carbon Dioxide Reforming of Methane over Ni Catalysts Supported on $\mathrm{Al}_{2} \mathrm{O}_{3}$ Modified with $\mathrm{La}_{2} \mathrm{O}_{3}, \mathrm{MgO}$, and CaO. Catal. Surv. Asia 2008, 12, 239-252. [CrossRef]

25. Herrera, J.E.; Resasco, D.E. In situ TPO/Raman to characterize single-walled carbon nanotubes. Chem. Phys. Lett. 2003, 376, 302-309. [CrossRef] 
26. Chen, J.; Yang, X.; Li, Y. Investigation on the structure and the oxidation activity of the solid carbon produced from catalytic decomposition of methane. Fuel 2010, 89, 943-948. [CrossRef]

27. Tsyganok, A. Dry reforming of methane over catalysts derived from nickel-containing $\mathrm{Mg}-\mathrm{Al}$ layered double hydroxides. J. Catal. 2003, 213, 191-203. [CrossRef]

28. Bradford, M.C.; Vannice, M.A. Catalytic reforming of methane with carbon dioxide over nickel catalysts I. Catalyst characterization and activity. Appl. Catal. A: Gen. 1996, 142, 73-96. [CrossRef]

(C) 2020 by the authors. Licensee MDPI, Basel, Switzerland. This article is an open access article distributed under the terms and conditions of the Creative Commons Attribution (CC BY) license (http://creativecommons.org/licenses/by/4.0/). 